\title{
Sponge spicule and phytolith evidence for Late Quaternary environmental changes in the tropical Pantanal wetlands of western Brazil
} \author{
Ivan Bergier ${ }^{f}$

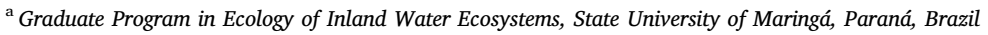 \\ ${ }^{\mathrm{b}}$ Department of Earth and Environmental Sciences, University of Kentucky, Lexington, KY, USA

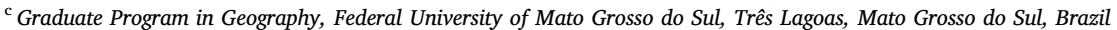 \\ ${ }^{\mathrm{d}}$ Laboratory of Paleoenvironmental Studies, State University of Paraná, Campo Mourão, Paraná, Brazil \\ e Department of Geography, Federal University of Mato Grosso do Sul-CPAN, Corumbá, Mato Grosso do Sul, Brazil \\ ${ }^{\mathrm{f}}$ Embrapa Pantanal, Corumbá, Mato Grosso do Sul, Brazil
}

Giliane G. Rasbold ${ }^{\mathrm{a}, *}$, Michael M. McGlue ${ }^{\mathrm{b}}$, José C. Stevaux ${ }^{\mathrm{a}, \mathrm{c}}$, Mauro Parolin ${ }^{\mathrm{d}}$, Aguinaldo Silva ${ }^{\mathrm{e}}$,

\section{A R T I C L E I N F O}

\section{Keywords:}

Biological indicators

Lake sediments

Lake Negra

Paleolimnology

Wetlands

\begin{abstract}
A B S T R A C T
The environmental history of the central Pantanal wetlands of western Brazil is inferred for the last $19 \mathrm{kyrs}$ based on a multi-indicator paleolimnological analysis of a sediment core from Lake Negra. The core, dated by ${ }^{14} \mathrm{C}$ and OSL, shows variations in the abundance, diversity, and preservation of sponge spicules and phytoliths through time, consistent with changing aquatic environments. In the late Pleistocene, Lake Negra was influenced by a strong monsoon and fluvial depositional processes, whereas in the Holocene, there was a drier interval where the lake was more isolated on the floodplain. Hiatuses in the stratigraphy resulted from both wet and dry conditions, through fluvial channel scour or subaerial exposure of the lake floor, respectively. Data suggest that floodplain lakes in the Pantanal wetlands and similar riverine wetlands respond in a complex and, at times, indirect manner to climate change, and the dynamics of the adjacent fluvial system must be accounted for when interpreting paleohydrology and vegetation patterns.
\end{abstract}

\section{Introduction}

Tropical wetlands are important to global biogeochemical cycling and patterns of biodiversity (Junk, 2002), but the response of many of these aquatic ecosystems to future environmental changes is still uncertain (e.g., Bridgham et al., 2013). A number of modeling studies have concluded that higher concentrations of atmospheric carbon dioxide $\left(\mathrm{CO}_{2}\right)$ could impart dramatic changes to tropical wetlands in the future, including an increase in the flux of methane $\left(\mathrm{CH}_{4}\right)$ to the atmosphere (Gedney et al., 2004; Shindell et al., 2008; Melton et al., 2013). Other studies note the key role that tropical wetlands may play in the future for carbon sequestration, which could counterbalance any net radiative forcing from $\mathrm{CH}_{4}$ emissions (Mitsch et al., 2013). Melton et al. (2013) suggest that $\mathrm{CH}_{4}$ flux from tropical wetlands due to increasing heterogeneity in the water cycle is less clear, which underscores the need for new paleohydrological research to expand our understanding of wetland function under different scenarios of water availability. At the regional scale, wetlands provide ecosystem services that are economically valuable, including opportunities for ranching, fishing, agriculture, and tourism (Bergier et al., 2018). Large riverine wetlands at low latitudes in the Americas (e.g., the Everglades, Llanos, and Pantanal), have received some attention for the threats posed to them by changes in precipitation, temperature, sea level, wildfire, agriculture, and urbanization (Foti et al., 2013; Junk et al., 2013). Due to their seasonal or "pulsing" hydrology, these wetlands are believed by Mitsch et al. (2010) to be particularly sensitive to changes in climate.

One way to add to our understanding of the response of tropical wetlands to environmental variability is through an examination of late Quaternary strata, which holds the promise of recording sedimentological and ecological changes. Yet tropical wetlands with pulsing hydrology pose unique challenges for the development of continuous stratal records, particularly from floodplain lakes. For example, the Pantanal of central South America, a lowland savanna floodplain type wetland, is strongly impacted by the annual flooding of the Paraguay River. The arrival of the Paraguay River flood pulse varies spatially and temporally within the Pantanal (Assine et al., 2015a). For many

\footnotetext{
*Corresponding author at: Graduate Program in Ecology of Inland Water Ecosystems, State University of Maringá, Av. Colombo, 5790, Room 9, Block G-90, 87.020-900, Maringá, Paraná, Brazil.

E-mail address: grasbold@gmail.com (G.G. Rasbold).
} 
floodplain lakes directly connected to the Paraguay River, rising stage elevation can influence lake level and therefore influence facies development (McGlue et al., 2011). The discharge, slope, sediment load, and channel morphology of the Paraguay River therefore also play roles in governing sedimentary processes for floodplain lakes, and these characteristics can be altered by processes other than climate, including landform evolution, fault movements, earthquakes, subsidence, and vegetation dynamics (Assine and Soares, 2004; Zani et al., 2012; McGlue et al., 2015; Assumpção et al., 2016; Dias et al., 2016). Nonetheless, pursuit of additional knowledge on how transitions in tropical climate have influenced the Pantanal since the Last Glacial Maximum remains an important task, since this information provides insight that can be used by water managers to inform policy, aid sustainable development, and build conservation plans. At present, only historical datasets are available for these tasks in the Pantanal (Bergier et al., 2018), but these data do not encompass the full range of environmental perturbations likely to affect the wetlands in the Anthropocene.

The large floodplain lakes on the western margin of the Paraguay River are among the best studied limnogeological systems in the Pantanal (Bezerra and Mozeto, 2008; McGlue et al., 2015). Today, these lakes are hydrologically open on a seasonal basis, but the strength of the outflow to the Paraguay River varies. Sedimentary records of environmental change from these lakes have proven complex, especially at Lake Gaíva (Mato Grosso do Sul state). For example, Whitney et al. (2011) and Metcalfe et al. (2014) analyzed pollen and diatom assemblages from Lake Gaíva, and they found evidence for a relatively cool and dry environment from $\sim 45.0$ to $19.5 \mathrm{kyr}$ BP. Those authors suggested that Pantanal remained dry until $\sim 12.8-12.2 \mathrm{kyr}$ BP, at which time the lake level rose, connecting Lake Gaíva to the Paraguay River. A later study using biomarkers made by Fornace et al. (2016) largely supported the results and interpretations of these earlier studies, indicating abundant $\mathrm{C}_{4}$ vegetation (grasses) and $\mathrm{C}_{3}$ herbs on the landscape from $\sim 41$ to $20 \mathrm{kyr} \mathrm{BP}$, with a peak in drought tolerant vegetation inferred from carbon isotopes at the Last Glacial Maximum (LGM). McGlue et al. (2012) documented the presence of mid-late Holocene unconformities in Lakes Gaíva and Mandioré, which were attributed to drought-induced lake level lowstands. Neither Whitney et al. (2011) nor Metcalfe et al. (2014) found evidence for drought in the mid-late Holocene.

Adding to the complexity of Pantanal's environmental history, a paleo-precipitation proxy record was produced from the Serra do Bodaquena (Mato Grosso do Sul) in southeastern Pantanal. A high resolution oxygen isotope record from Jaraguá cave speleothems indicated that the region experienced a strong monsoon during the LGM $(\sim 27.9-17.8 \mathrm{ka})$ and a relatively dry early-mid Holocene (Novello et al., 2017). The cave proxy data for the late Pleistocene appear to conflict with the pollen and diatom records from Lake Gaíva, but support the presence and severity of dry conditions at the transition into the late Holocene. Novello et al. (2017) suggested that changes in vegetation may have been decoupled from precipitation patterns of the last glacial maximum. It is also plausible that the complex depositional setting along the margin of the Paraguay River may decouple prevailing environmental conditions from the information recorded in lake sediments. It is therefore valuable to examine floodplain lake records other than those from Lake Gaíva, which could provide independent evidence of changing environmental conditions in the late Pleistocene and Holocene.

The purpose of this study is a paleocological and sedimentological analysis of a sediment core collected from Lake Negra (LN), which is a large floodplain lake connected to the Paraguay River (Fig. 1A), situated about $150 \mathrm{~km}$ south of Lake Gaíva (Fig. 1A) and $\sim 200 \mathrm{~km}$ northwest of the Jaraguá cave (Fig. 1A). Lake Negra's hydrological balance is controlled by the arrival of the Paraguay River flood pulse in the late austral summer and fall. We used siliceous microfossils and carbon content from a well-dated lake sediment core from LN to document environmental changes since $\sim 19 \mathrm{ka}$. The results add to a growing spatial network of Quaternary lake sediments datasets for Pantanal and help illustrate how hydroclimatic signals are recorded in floodplain lakes.

\section{Geological setting}

The Pantanal is a tectonically active sedimentary basin that most likely formed due to the Andean orogeny in the Tertiary (Ussami et al., 1999; Assine et al., 2015a). The Pantanal is a lake-rich lowland basin situated at $\sim 16-21^{\circ} \mathrm{S}$ latitude and $\sim 55-58.5^{\circ} \mathrm{W}$ longitude (Cohen et al., 2015). Drained north to south by the Paraguay River (PR), the Pantanal is considered one of the largest natural wetlands in the world; it extends over $\sim 150,000 \mathrm{~km}^{2}$ covering areas of western Brazil in Mato Grosso and Mato Grosso do Sul states, and small areas of eastern Bolivia and Paraguay (Por, 1995; Assine et al., 2015a). The geology surrounding the study site is comprised of Quaternary sediments, such as the Xaraiés and Pantanal Formations that make up alluvial terraces and colluvial deposits (Brasil Ministério de Minas e Energia, 1982; Lacerda Filho et al., 2006). The lowland landscape is intermittently fringed by hills that consist of ancient meta-sedimentary rocks, such as the Morraria do Urucum, Tromba dos Macacos, Jacadigo, Santa Cruz, São Domingos, Grande, and Rabichão, which belong to the Urucum and Santa Cruz Formations of the Neoproterozoic Jacadigo Group. Localized outcrops of Bocaina and Tamengo Formation (Neoproterozoic Corumbá Group) limestones are also present (Brasil Ministério de Minas e Energia, 1982; Lacerda Filho et al., 2006).

The climate of the Pantanal is influenced by the Intertropical Convergence Zone (ITCZ) and by the South American summer monsoon (SASM) (Zhou and Lau, 1998; Garreaud et al., 2009; Vuille et al., 2012). A prominent wet season occurs from October to April. In general, high precipitation occurs in the months of December, January and February in the northern and central portion of the Pantanal (McGlue et al., 2011). Vegetation in the Pantanal is a mosaic of different types (Brasil Ministério de Minas e Energia, 1982). Seasonal flooding patterns, local topography, and soils are the main controls on the distribution of plant life, which Pott and da Silva (2015) described as "self-organized chaos". Terrestrial plants in the Pantanal include deciduous seasonal forests, semi-deciduous seasonal forests, and cerrado (savanna). Both lotic and lentic aquatic vegetation types are present, and zonation is dependent on water depth; plants may be floating, partially submerged, or rooted (Pott and da Silva, 2015).

Ab'Saber (1988) classified the lakes of the Pantanal into four distinct types, taking into account formation processes, shape, depth, and residence time. These lake types are: (i) oxbow lakes, (ii) small circular lakes (ovate ponds, especially those formed on the Taquari River megafan, (iii) karst lakes, and (iv) large floodplain lakes. Floodplain lakes are typically shallow and can be maintained on the landscape for hundreds to thousands of years, through a combination of surface water inflows, groundwater infiltration, and direct precipitation (Hutchinson, 1957; Cohen, 2003). The largest lakes in the Pantanal are on the floodplain of the Paraguay River and are located on the western border of the basin, including Lakes Gaíva, Mandioré, Baía Vermelha, Cáceres, Castelo, Negra and Uberaba (McGlue et al., 2011).

Lake Negra has an area of $\sim 10.8 \mathrm{~km}^{2}$ with an irregular shape. The lake has a maximum long axis length of $\sim 4.1 \mathrm{~km}$ and a maximum width of $\sim 3.5 \mathrm{~km}$ (Bezerra and Mozeto, 2008). The bathymetry of LN is relatively simple, with gradually increasing water depths towards the basin center that reach $\sim 2.6 \mathrm{~m}$ when the Paraguay River is flooded. The southeastern border of $\mathrm{LN}$ is at the base of Ladário Mountain (maximum elevation is $\sim 150 \mathrm{~m}$ above sea level); the higher elevations are colonized by seasonal forest with abundant Bromeliaceae and Cactaceae. The water inputs to LN include direct precipitation on the lake surface, local river channels (e.g., the Banda Alta Stream that drains the Urucum Massif), and inflow from Paraguay River floods during the wet season. Along the northwestern margin of LN, a natural tie channel formerly connected the lake to the Paraguay mainstem, but a road built across 

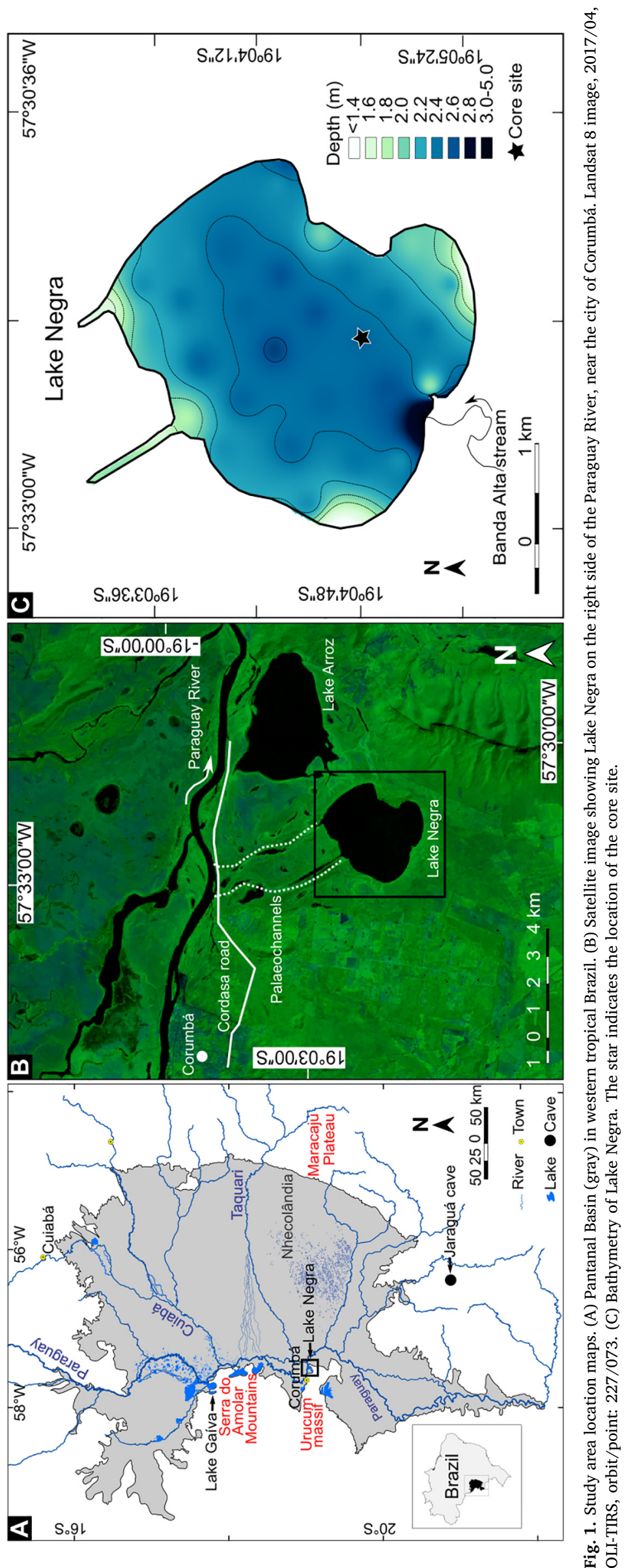
that channel in 1974 separated the lake from the river (Fig. 1B). Today, that abandoned channel exists on the floodplain as a periodically inundated swamp. Following the construction of the road, a Paraguay River flood formed a new permanent lake (Lagoa do Arroz) to the northeast of LN (Bezerra, 1998).

The modern limnogeology of LN provides important context for understanding its sedimentary archives. Today, LN has a $\mathrm{pH}$ of 6.5-7, high alkalinity (853.7-1281.5 $\mathrm{mg} \mathrm{CaCO}_{3} / \mathrm{L}$ ), low electrical conductivity $(32.2-130.6 \mu \mathrm{S} / \mathrm{cm})$ and turbidity values that range from $\sim 30$ to 197 NTU, with maximum values typically encountered on the southwestern lake margin. Modern sediments accumulating on the LN floor consist of clays and silts; a small delta that deposits sand and gravel forms on the southern shoreline, where the Alta Banda Stream enters the lake (Fig. 1).

\section{Material and methods}

Bezerra (1998) retrieved two sediment cores from adjacent boreholes in LN in 1995 via vibro-coring (LN95/L1 and LN95/L2) (Fig. 1C). Details about core LN95/L1, including its age-depth model, appear in Bezerra and Mozeto (2008). Core LN95/L2 was kept in cool, dry storage prior to opening in 2016. The core was opened in a dark room at the Federal University of Mato Grosso do Sul, Pantanal Campus, in order to facilitate the collection of sand samples for OSL dating. Core LN95/L2 was photographed and described following the methods outlined in Schnurrenberger et al. (2003). Discrete sediment sub-samples were collected every $3 \mathrm{~cm}(n=87)$ along the length of the core, in order to analyze sponge spicules and plant phytoliths, as well as for total carbon.

The stratigraphy of LN95/L2 is virtually identical to the LN95/L1 core, allowing the correlation of strata and ${ }^{14} \mathrm{C}$ dates reported on by Bezerra (1998) and Bezerra and Mozeto (2008) (Table 1, Fig. 2). Two prominent sand beds were sampled for OSL dating. The OSL dating followed the SAR protocol (Wallinga et al., 2000) at Dating, Trade, and Provision of Services Ltd., São Paulo (Table 2). The SAR protocol obtains a mean age derived from samples with a minimum of five aliquots. The samples were subjected to chemical treatment with $\mathrm{H}_{2} \mathrm{O}_{2}, \mathrm{HF}$, and $\mathrm{HCl}$ to isolate quartz. Following chemical pre-treatment, the samples were dried and passed through 100-60 mesh $(0.149-0.25 \mathrm{~mm})$ Tyler sieves. For the two dated horizons in LN95/L2, 15 aliquots were measured from each horizon, though only one aliquot $(\sim 7 \mathrm{mg})$ was used for the determination of paleodose (P). Values of equivalent dose, tests for recycling and tests for recovery of each aliquot were obtained, from which the annual dose rate ( $\mu \mathrm{Gy} / \mathrm{yr}$ ), paleodose average (Gy) and average age (years) were derived (Table 2).

All radiocarbon dates in Bezerra (1998) and Bezerra and Mozeto (2008) (Table 1), as well as new OSL dates, were input into BACON for $\mathrm{R}$ in order to generate an age-depth model (Blaauw and Christen, 2011) (Fig. 3). The radiocarbon dates were calibrated using the SHCal13 curve (Hogg et al., 2013), and the post-bomb date at $1 \mathrm{~cm}$ was calibrated using the SH3 post-bomb calibration curve (Hogg et al., 2013; Hua et al., 2013). The visual stratigraphy of the LN95/L2 suggested the presence of three hiatuses, at $\sim 60,180$, and $240 \mathrm{~cm}$ below the lake floor; these were input into the BACON model with an estimated length of $\sim 1000 \mathrm{yr}$. The accumulation rate mean was set at 50 years $/ \mathrm{cm}$ and an alternative depth was set at $272 \mathrm{~cm}$, the base of the core.

Sponge spicules and phytoliths were extracted at the Paleoenvironmental Studies Laboratory (Lepafe), following a modified protocol of Volkmer-Ribeiro (1985). In brief, the procedure called for the following: (i) each sample was oven dried, crushed, and $\sim 1 \mathrm{~g}$ of sediment was packed into a clean test tube, (ii) $\sim 5 \mathrm{ml}$ of $\mathrm{HNO}_{3}$ was added to each test tube, (iii) the sediment samples plus acid were heated to a boil and allowed to react overnight, (iv) the samples were washed with distilled water until a neutral $\mathrm{pH}$ was achieved, (v) $\sim 50 \mu \mathrm{l}$ of acidified sample was dripped onto a cleaned microscope slide and dried on a hot plate, and (vi) Entellan ${ }^{\circledR}$ resin and a coverslip were used to fix the sample.

Sponge spicules and plant phytoliths were counted and identified on three randomly selected transects on each slide, and three slides were prepared for each sample. Thus, nine transects per sample were assessed for the sponge spicule analysis, and an average of 315 spicules were counted per sample. Taxonomic identification was performed through systematic observations of the slides and distinguishing among the different sponge skeletal elements (megascleres, gemmuloscleres, and microscleres). Identification of different species followed the sponge identification key of the Class Demospongiae Sollas, 1885, Order Spongillida Manconi and Pronzato, 2002 - proposed by Morrow and Cárdenas (2015). Sponge abundances were classified using the following observation system: 1-3 observations (very rare), 4-6 observations (rare), 7-10 observations (common), and $>11$ observations (abundant). Where sponge assemblages were characteristic of typical aquatic environments, we classified those intervals as spongiofacies, as defined by Parolin et al. (2008). The sponge spicules were recorded in two ways. Images of sponge spicules (gemmuloscleres and microscleres) were obtained with a scanning electron microscope (FEI, model Quanta 250) at the Laboratory of Biomass Conversion, Embrapa Pantanal, Corumbá, Brazil and photomicrographs of the other biological indicators were collected using an optical microscope $(\times 640$ magnification). For internal consistency, a single analyst (GGR) completed the sponge spicule analysis. Morphological identification and quantification of plant phytoliths followed the International Code for Phytolith Nomenclature 1.0 (Madella et al., 2005). Spicule assemblages and phytoliths were statistically sorted into zones using a stratigraphically constrained cluster analysis in CONISS ${ }^{\circledR}$ in the Tilia $^{\circledR}$ program (Grimm, 1987).

An additional split of each sediment sample was freeze-dried, ground, and analyzed for weight percent total organic carbon (TOC), which provides an indicator of processes responsible for organic enrichment of the lake sediments, including biological productivity, preservation, and dilution. Total carbon (TC) content was determined on a LECO SC-144DR device and total inorganic carbon (TIC) on a UIC ${ }^{\mathrm{TM}}$ carbonate coulometer at the Kentucky Geological Survey. The precision of the TIC analysis was $\pm 0.2 \%$, whereas the precision for TC was better than $1.0 \%$. The TOC was computed as the mass difference between LECO-derived TC and coulometry derived TIC values.

Table 1

Radiocarbon dates used in the age-depth model for LN95/L2 (Lake Negra).

\begin{tabular}{|c|c|c|c|c|c|c|}
\hline Depth $(\mathrm{cm})$ & Lab code & $\delta^{13} \mathrm{C}(\% 0)$ & $\begin{array}{l}\text { Age } \\
\left({ }^{14} \mathrm{C} \text { yr BP }\right)\end{array}$ & Error & $\begin{array}{l}\text { 2- } \sigma \text { range } \\
\text { (cal yr } \mathrm{BP} \text { ) }\end{array}$ & Material \\
\hline $21-30$ & WAT- $4036^{\mathrm{a}}$ & -26.3 & 1060 & 90 & 1093-731 & TOC \\
\hline $60-70$ & WAT-2967 ${ }^{\mathrm{a}}$ & -19.3 & 5190 & 90 & $6121-5698$ & TOC \\
\hline $101-110$ & WAT- $4037^{\mathrm{a}}$ & -25.0 & 7480 & 160 & $8545-7953$ & TOC \\
\hline $125-135$ & WAT- $2975^{\mathrm{a}}$ & -23.4 & 8770 & 120 & $9975-9531$ & TOC \\
\hline $181-191$ & WAT-2976 ${ }^{\mathrm{a}}$ & -23.4 & 10,200 & 190 & $12,431-11,229$ & TOC \\
\hline $243-254$ & TO-6178 & -22.9 & 14,870 & 160 & $18,429-17,640$ & TOC \\
\hline
\end{tabular}

\footnotetext{
a Liquid scintillation counting.

b Accelerator mass spectrometry; Material: Total organic carbon (TOC). See text for details.
} 


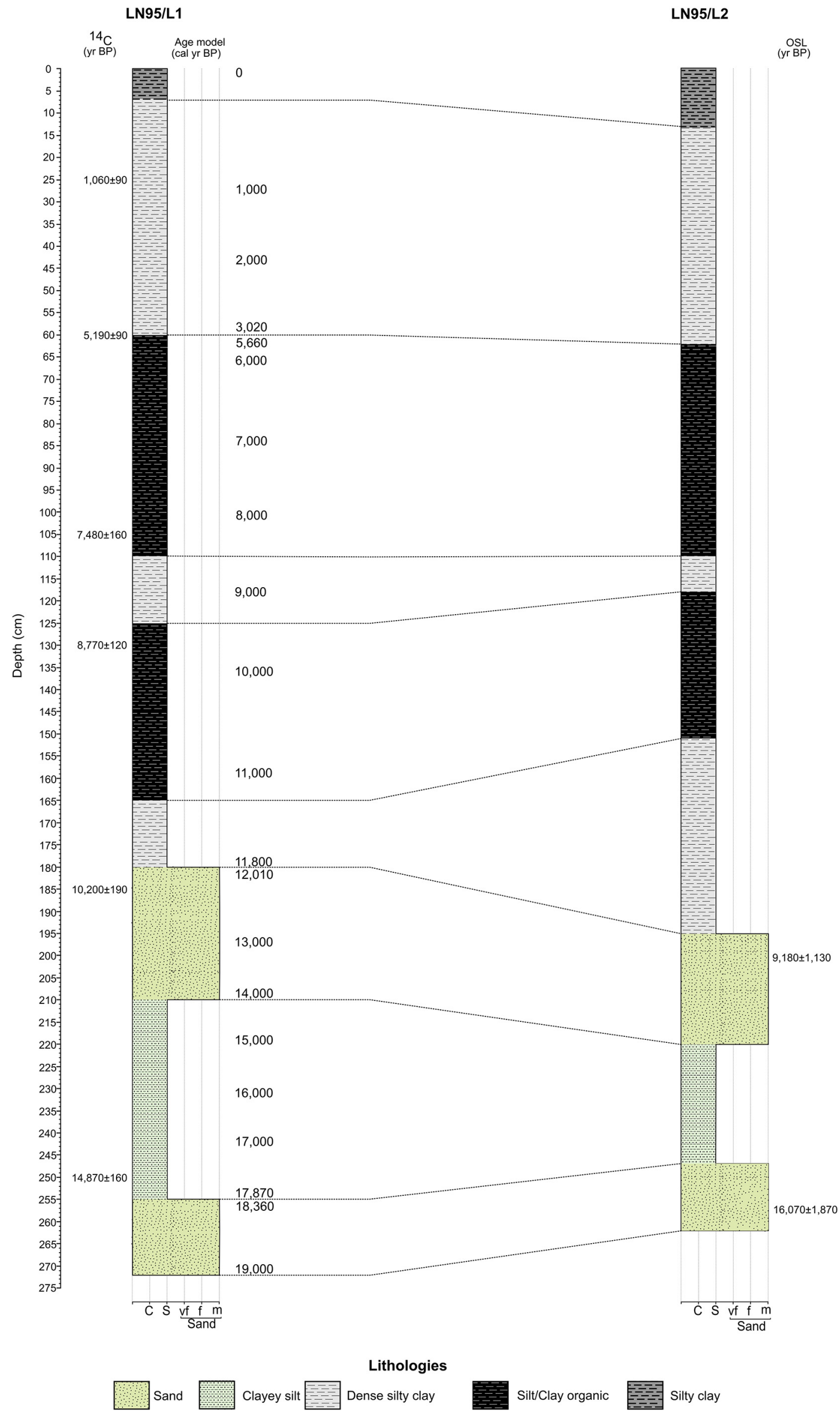




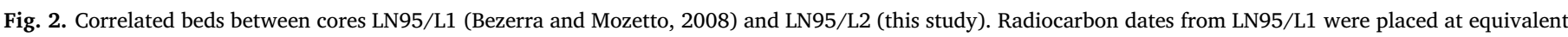

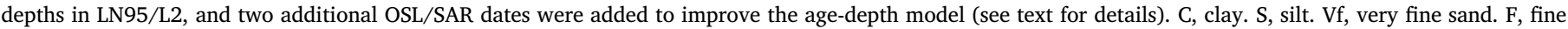
sand. M, medium sand.

\section{Results and interpretations}

Analysis of megascleres, gemmuloscleres, and microscleres revealed seven different freshwater sponge species of the family Spongillidae Gray, 1867 (Fig. 4): Corvoheteromeyenia heterosclera (Ezcurra de Drago, 1974) (Fig. 5 A-D), Corvospongilla seckti Bonetto \& Ezcurra de Drago, 1966, Dosilia pydanieli Volkmer-Ribeiro, 1992, Heteromeyenia barlettai Pinheiro, Calheira \& Hajdu, 2015 (Fig. 5E), Tubella variabilis Bonetto \& Ezcurra de Drago, 1973 (Fig. 5F), Tubella paulula (Bowerbank, 1863) (Fig. 5G), and Radiospongilla amazonensis Volkmer \& Maciel, 1983 (Fig. 5H). For the phytoliths, several botanical families were evident (Figs. 4, 5) including abundant Poaceae (bilobate, cross, saddle, and rondel short cells and cuneiform and parallepipedal bulliforms) and lesser abundances of dicotyledons (globular granulate and psilate), Bromeliaceae (globular echinate), and Areaceae (globular echinate). The assemblages of sponge spicules and phytoliths were used to define six units within the core using cluster analysis (labeled I-VI, from oldest to youngest, respectively).

\subsection{Stratigraphy and geochronology}

Core LN95/L2 chiefly consists of dark, massively bedded muds and green-grey sands (Figs. 2 and 4). Most of the bedding contacts in the core are gradational, however sharp and distinct contacts separate units I and II, III and IVa, and V and VI. Mud-over-sand transitions mark the Unit I-II and III-IVa contacts, which we interpret as evidence for fluvial scour in an environment marked by strong riverine baseflow and flooding. In contrast, the contact separating units V and VI is marked by the presence of a thin, light brown-red silty clay layer containing sandsized iron oxide nodules overlying much darker, lower density muds. We attribute this sedimentology, and the associated abrupt transition in the biological indicators, to reflect subaerial exposure of the LN floor, most likely due to late Holocene drought. We used this information to condition the BACON age-depth model by placing hiatuses at these contacts. Six ${ }^{14} \mathrm{C}$ dates and two OSL dates were used to generate an agedepth model for LN95/L2 in BACON (Fig. 3). The model produced by BACON generates a good fit for all of the dated horizons, with three multi-centennial gaps where section is missing (Hiatus $\mathrm{I}=\sim 18,360-17,870 \mathrm{cal}$ yr BP, Hiatus $\mathrm{II}=\sim 12,010-11,800$ cal yr BP, and Hiatus III $=\sim 5660-3020$ cal yr BP).

\subsection{Unit I (19,000-18,360 cal yr BP)}

Unit I (260-240 cm below lake floor [cmblf]) consists of massive green muddy sands that lack obvious sedimentary structures or macrofossils. Phytoliths and sponge spicules are absent in this unit (Fig. 4). The TOC concentrations were uniformly below the detection limit, whereas concentrations of TIC were very low (0.02-0.06 wt.\%).

We interpret Unit I to indicate a fluvial-lacustrine paleoenvironment (Fig. 4). Sand encountered in the core suggests that considerable Paraguay River flooding was occurring at this time, and it is plausible that a secondary channel of the Paraguay mainstem was positioned adjacent to the coring site. The absence of biological indicators may be due to the strength of the riverine flow and abrasion of fossils by suspended silts or bedload sands.

\subsection{Unit II $(17,870-15,000$ calyr BP)}

Overlying a hiatus at the top of Unit I, Unit II (240-205 cmblf) consists of massively bedded fine grained sandy mud. The base of Unit II is green and it transitions into a mottled green color near the upper contact. Phytoliths and sponge spicules are present but in low total concentrations ( $<50$ phytoliths and $<250$ spicules). The phytolith morphologies present are dominated by bulliform cuneiform, parallepipedal, and elongate psilate (Figs. 4, 5). The sponge spicules in Unit II are dominantly megascleres with varying degrees of taphonomic overprint, ranging from mostly intact fossils to extensively damaged fragments. No morphologies were present that allowed species identification. Unit II TOC concentrations range up to $\sim 1.0 \mathrm{wt} . \%$, whereas TIC reaches the maximum encountered in the core, with values up to $\sim 0.16$ wt.\% (Fig. 4).

We interpret Unit II to reflect deposition in a floodplain paleoenvironment characterized by ephemeral wetlands that received occasional riverine inputs (Figs. 4, 6). The sponge spicules may have been fragmented during transport through grain impacts, or following deposition due to bioturbation, as mottling suggests a fluctuating redox front. Carbonate precipitation in this environment suggests that evaporation of standing water was a common process, potentially resulting from long dry seasons. Bulliform phytolith morphologies that were deposited in this unit are consistent with water stress in floodplain grasses (Parry and Smithson, 1958; Sangster and Parry, 1969; Bremond et al., 2005).

\subsection{Unit III $(15,000-12,010$ cal yr BP)}

Unit III (205-180 cmblf) comprised mottled sandy mud that grades into green medium sand. The sands in Unit III are fine grained and lack sedimentary structures. Siliceous microfossils are absent from Unit III, and TOC and TIC concentrations are minimal (Fig. 4).

We interpret Unit III as an interval when LN was strongly influenced by pulses of seasonal flooding from the Paraguay River that reached the core site by a secondary channel associated with the Paraguay, similar to Unit I (Figs. 4, 6).

\subsection{Unit IVa $(11,800-11,000$ cal yr BP)}

Unit IVa (180-155 cmblf) overlies hiatus II and consists of medium green sands that transition upward into gray sandy muds. Concentrations of both TOC and TIC are very low throughout Unit IVa. Sponge gemmuloscleres and microscleres are absent, and the total presence of megascleres is limited ( $<250$ spicules). These megascleres are characterized by heavy taphonomic damage; spicule fragmentation was moderate-to-high in $\sim 75 \%$ of the microfossils examined. The concentration of phytoliths is low ( $<70$ fossils). The predominant phytolith morphologies are robust, such as bulliform parallepipedal, cuneiform, and elongate psilate. Bulliform morphologies

Table 2

Equivalent doses, dose rates and OSL/SAR ages for the studied samples from LN95/L2 obtained from Lake Negra.

\begin{tabular}{|c|c|c|c|c|c|c|c|c|c|}
\hline ID & Depth $(\mathrm{cm})$ & $\begin{array}{l}\text { Th } \\
\text { (ppm) }\end{array}$ & $\begin{array}{l}\mathrm{U} \\
(\mathrm{ppm})\end{array}$ & $\begin{array}{l}\mathrm{K} \\
(\%)\end{array}$ & $\begin{array}{l}\text { Water content } \\
(\%)\end{array}$ & Annual dose rate $(\mu \mathrm{Gy} / \mathrm{yr})$ & Aliquots & P (Gy) & OSL age (yr) \\
\hline 4897 & $180-188$ & $5471 \pm 299$ & $1570 \pm 137$ & $1351 \pm 272$ & 1.8 & $2230 \pm 225$ & 15 & 20.5 & $9180 \pm 1130$ \\
\hline 4907 & $250-262$ & $6321 \pm 311$ & $1969 \pm 143$ & $1248 \pm 239$ & 4.2 & $2260 \pm 195$ & 15 & 36.5 & $16,070 \pm 1870$ \\
\hline
\end{tabular}




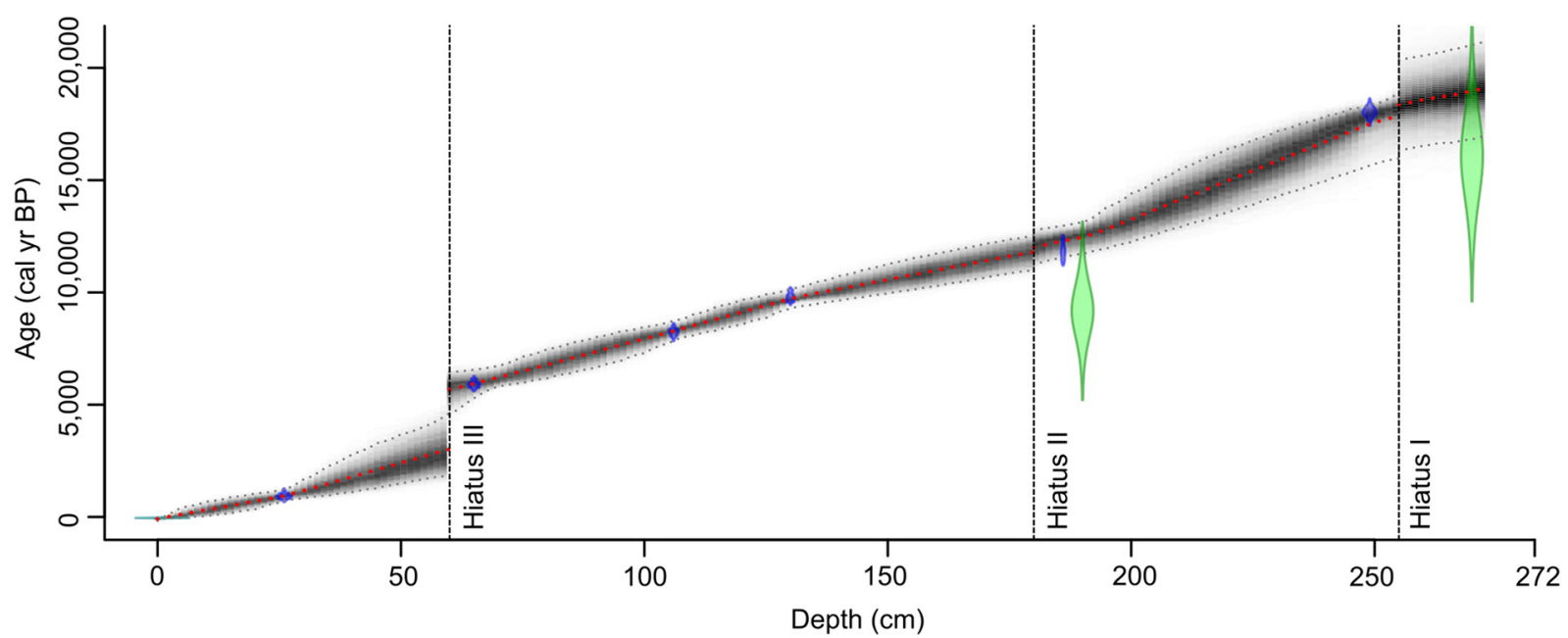

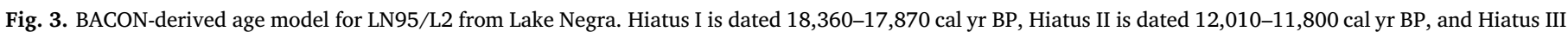

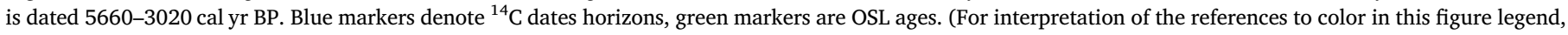
the reader is referred to the web version of this article.)

(parallepipedal and cuneiform) are indicators of water stress in plants, especially grasses that can tolerate long dry seasons and high evapotranspiration (Parry and Smithson, 1958; Sangster and Parry, 1969; Bremond et al., 2005).

The biological indicators and damage patterns to spicules suggest the periodic influence of Paraguay River floods on the depositional environment. The high ratio of fragmented to whole megascleres suggests occasional floodplain inundation with variable persistence of ponded water (Kuerten et al., 2013). The phytolith assemblage of Unit IVa is interpreted to reflect the presence of herbaceous vegetation and soils with relatively low moisture in the LN watershed during deposition.

\subsection{Unit $I V b-155-90 \mathrm{~cm}(11,000-8000$ cal yr BP $)$}

Unit IVb (155-90 cmblf) consists of dark gray silty clays and light gray clays with charcoal. In this unit, TOC concentrations rise to $2.0 \mathrm{wt}$.\%, whereas TIC remains very low. Unit IVb is marked by a large increase in the diversity and abundance of sponge megascleres $(>1000$ total spicules). Sponge spicules from $C$. heterosclera, $R$. amazonensis, $T$. paulula, T. variabilis, and C. seckti are present in rare to very rare abundances. The concentration of phytoliths reaches a peak of $\sim 380$ fossils per sample in this unit. Globular morphologies such as globular echinate (Bromeliaceae - Piperno, 1985, 2006; Bremond et al., 2005 and Arecaceae - Piperno, 2006; Runge, 1999; Mercader et al., 2009), globular granulate and psilate (woody dicotyledons), bilobate $\left(\mathrm{C}_{4}\right.$ mesophytic grasses), rondel $\left(\mathrm{C}_{3}\right.$ grasses $)$, and saddle $\left(\mathrm{C}_{4}\right.$ xerophytic grasses) were present (Bremond et al., 2005) (Fig. 5).

The vegetation succession around LN based on the phytolith record suggests that an environmental change took place between Unit IVa and IVb. Bulliform phytolith morphologies in Unit IVa suggest a relatively dry paleoenvironment that, when coupled with the sedimentological characteristics, are best interpreted as an ephemerally inundated floodplain associated with a secondary channel of the Paraguay River. By contrast, in Unit IVb, the phytoliths suggest the presence of a diverse mixture of vegetation, including both $\mathrm{C}_{3}$ and $\mathrm{C}_{4}$ plants. Moreover, the sedimentology of Unit IVb is most consistent with a shallow lacustrine paleoenviroment with relative water column stability that allowed delicate lentic sponge spicules to be preserved. Carbon coulometry data show that this paleo-lake accumulated organic matter, suggesting environmental conditions favorable for aquatic primary production and preservation and lower potential for dilution, even in light of slightly higher sedimentation rates.

\subsection{Unit V (8000-5660 calyr BP)}

Unit V (90-60 cmblf) consists of interbedded light gray sandy clay and dark gray clay. Unit $\mathrm{V}$ is distinguished by high concentrations of TOC (up to $\sim 7.0$ wt.\%) and an upward increase in phytoliths, sponge megascleres, and gemmuloscleres. Preservation of sponge spicules is excellent in Unit $\mathrm{V}$, in evidence by abundant whole microscleres of $C$. heterosclera, and $H$. barlettai. Spicules of T. paulula, T. variabilis, $R$. amazonenses, D. pydanieli, and C. seckti were also present, in rare to very rare abundances. Unit $\mathrm{V}$ is interpreted as a spongiofacies from 6500 to 5700 cal yr BP due to the abundance of spicules. For the phytoliths, we observed a reduction in the robust bulliform and elongate psilate morphologies and an increase in the concentration of bilobate morphological characteristics of the subfamily Panicoideae (Poaceae), indicating wetter conditions either across the region, or an increase in soil moisture around LN (Coe et al., 2014).

We interpret Unit $\mathrm{V}$ to reflect a perennial lacustrine paleoenvironment with relatively constant water levels based on the abundance of $C$. heterosclera and $H$. barlettai, the near pristine state of spicule preservation, and high concentrations of sedimentary organic carbon, which suggests elevated primary productivity and preservation (Figs. 4, 5). C. heterosclera has been characterized as an indicator species of shallow lakes among dunes in tropical Brazil (Volkmer-Ribeiro and Machado, 2007). However, there are records of this species for several habitat types, including ephemeral freshwater ponds in the Nhecolândia lake district of the Pantanal (Guerreiro et al., 2018). C. heterosclera is the most widely distributed freshwater sponge species in the Brazilian state of Pernambuco, and it has been found in aquatic environments affected by pollution (Nicacio and Pinheiro, 2015). Calheira and Pinheiro (2016) consider it an endemic from Neotropical Region species that can resist adverse conditions. A spongiofacies of Metania spinata Carter, 1881, T. variabilis, $R$. amazonensis and Heterorotula fistula Volkmer \& Motta, 1995 was reported as characteristic of an isolated lentic environments on the Nabileque megafan $\sim 3900 \mathrm{yr}$ BP (Kuerten et al., 2013). H. barlettai was abundant and consistently encountered in the upper sediments of Unit V. Little data exists on natural ecological preferences and distribution of this species, but aquarium specimens in São Paulo (Pinheiro et al., 2015) suggest that it can thrive in lentic environments, adhering to leaves, roots of aquatic plants, and tree trunks. We interpret the presence of this species to reflect a seasonal influence of riverine floodwaters entering LN. 


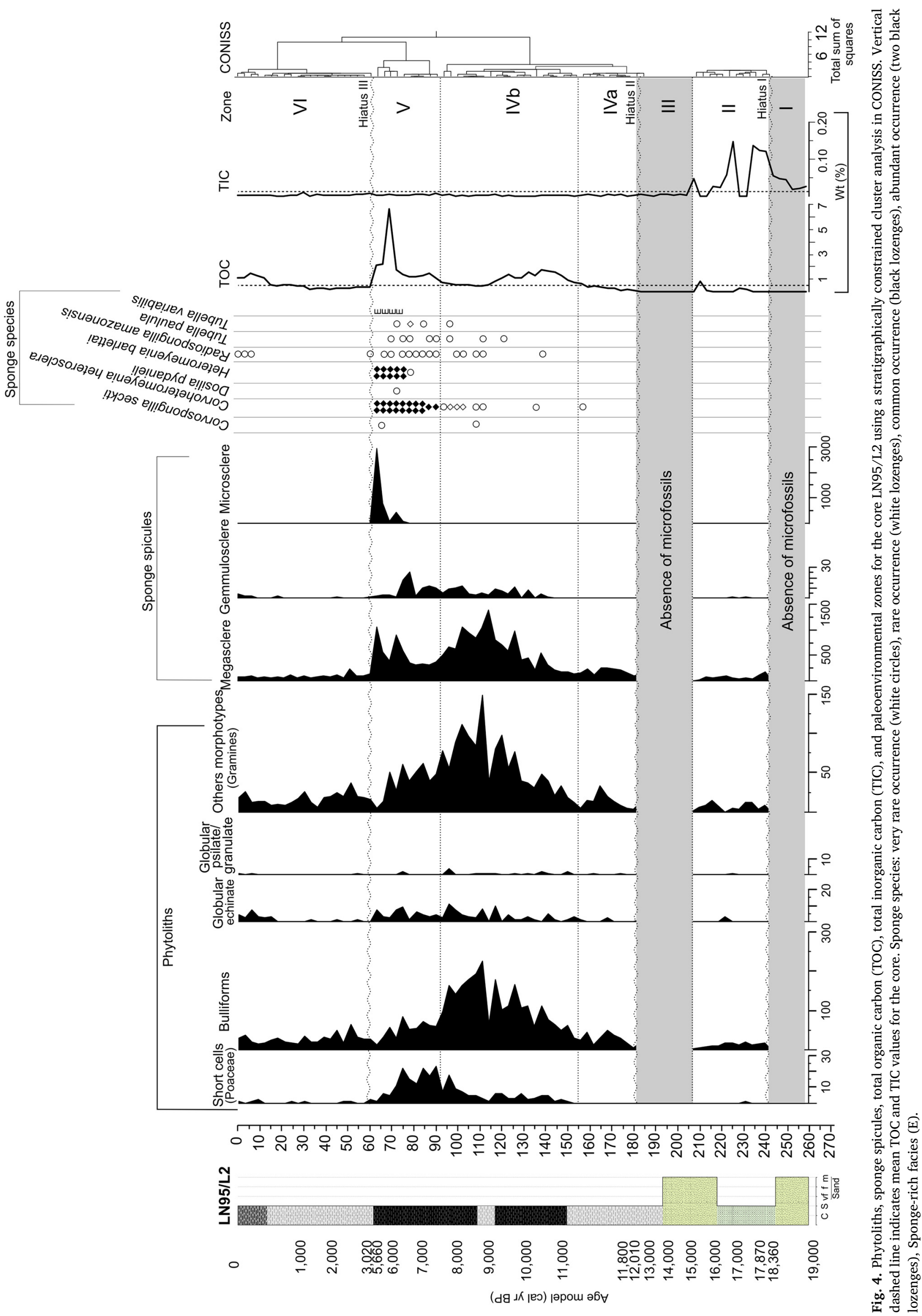




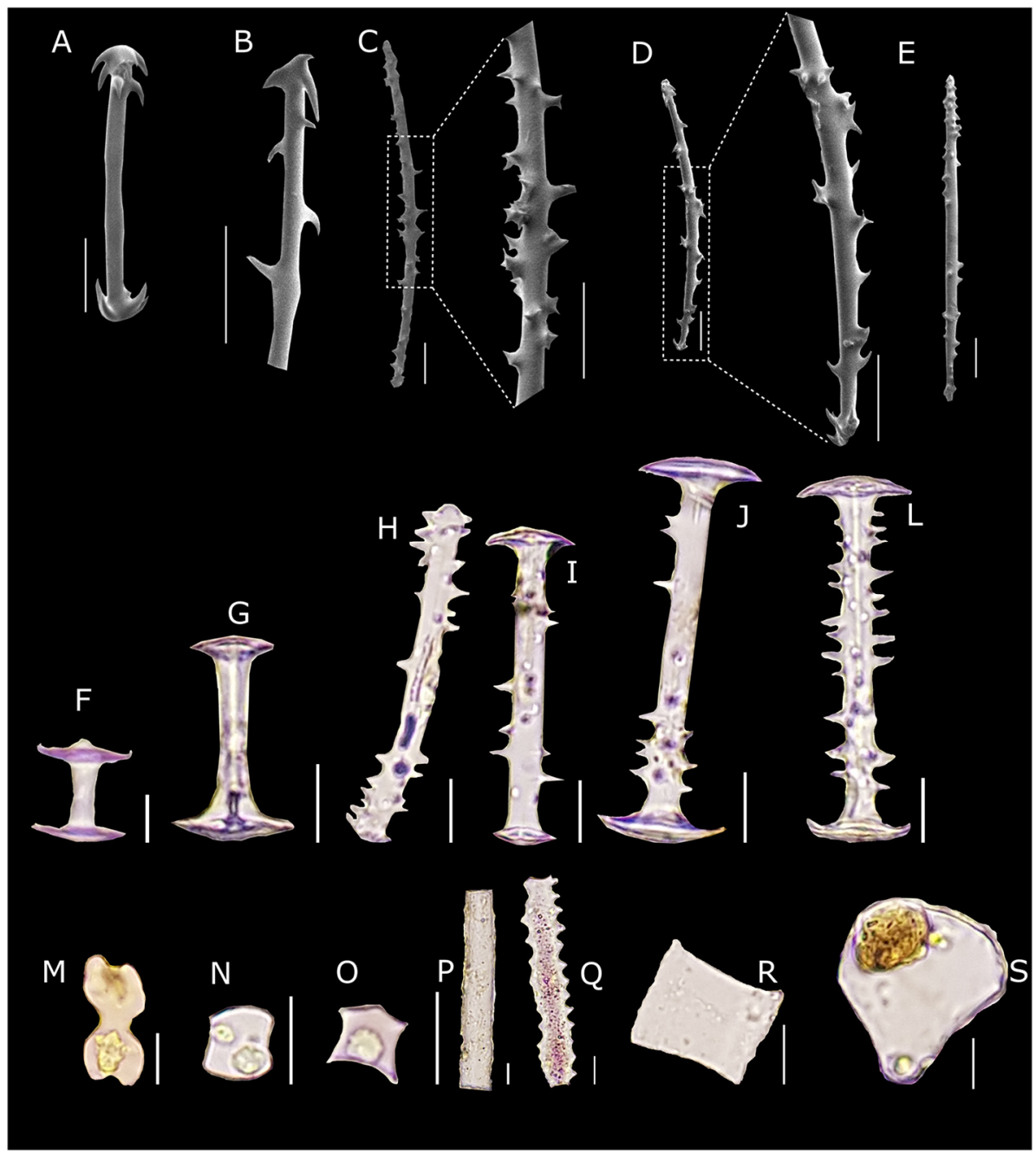

Fig. 5. Scanning electron micrographs of freshwater sponge spicules (A-L) and phytoliths (M-S) from late Quaternary sediments of Lake Negra. (A) Pseudobirotule microsclere with pseudobirotules of long hooks. (B) Pseudobirotule microsclere with pseudobirotules of short hooks. (C-D) Acanthoxea microscleres. (E) Acanthoxea microsclere. (F) Gemmulosclere birotule of Tubella variabilis. (G) Gemmulosclere birotule of Tubella paulula. (H) Gemmulosclere spiny strongyles of Radiospongilla amazonensis. (I). Gemmulosclere birotule with a long spiny shaft. (J-L) Gemmuloscleres birotules with a long spiny shaft of Heteromeyenia barlettai. (M) Bilobate. (N) Saddle. (O) Rondel. (P) Elongate psilate. (Q) Elongate echinate. (R) Parallepipedal bulliform. (S) Cuneiform bulliform. All scale bars $=10 \mu \mathrm{m}$.

\subsection{Unit VI (3020 cal yr BP to the present)}

Unit VI (60-0 cmblf) consists of massive gray-green clay overlying a prominent layer of reddish-brown silty clay that defines the unconformable Unit V-Unit VI contact. Towards the top of the unit, Unit VI muds become dark brown, and TOC concentrations rise to a maximum of $\sim 2.0 \mathrm{wt} . \%$ from $\sim 1000$ cal yr BP to the present. The abundance of microfossils abruptly decreases in Unit VI $(<100$ phytoliths, $<200$ megascleres, $<4$ gemmuloscleres, and 1 microsclere). For the sponges, $R$. amazonensis was identified at the top of the unit (Fig. 4). The predominant phytoliths are the robust bulliform cuneiform, parallepipedal, and elongate psilate morphologies. After $\sim 1000$ cal yr BP, globular echinate phytoliths (Bromeliaceae - Piperno, 1985, 2006; Bremond et al., 2005 and Arecaceae - Piperno, 2006; Runge, 1999; Mercader et al., 2009) are encountered in the core sediments. These phytoliths correspond to the vegetation growing in the area surrounding the lake today. For example, bromeliads are dominant in the Ladário Mountain on the western boundary of the lake, and specimens of Copernica alba (Carandá-Arecaceae) are a major component of the flora to the northwest and southwest of LN.

Unit VI reflects the transition from a period of very dry conditions that produced Hiatus III into a wetter paleoenvironment. The biological indicators and core sedimentology are most consistent with a small, shallow permanent lake environment, mostly similar to modern LN, at the coring site by $\sim 1000 \mathrm{yr} B \mathrm{P}$.

\section{Discussion}

The Pantanal region is still difficult to access and sample, and as a result, relatively few studies have appeared that contain paleoenvironmental information for the Pleistocene-Holocene transition (McGlue et al., 2015). Lake records that cover the Last Glacial Maximum and deglacial are rare, and those that do exist provide different information on the environmental conditions. For example, palynological data from Lake Gaíva suggests drier and cooler conditions than present from 42.0 to 19.5 kyr BP (Whitney et al., 2011). Similarly, diatom paleoecology suggests that from 24.5 to $13.1 \mathrm{kyr}$ BP, Lake Gaíva was very shallow (Metcalfe et al., 2014). Metcalfe et al. (2014) also indicate rapid hydroclimate changes from $\sim 12.2$ to $11.8 \mathrm{kyr} \mathrm{BP}$, with strong flooding alternating with brief dry periods. By contrast, lithofacies and sponge spicules from the Nhecolândia region of the Pantanal show that extant saline lake environments were likely occupied by rivers in the latest Pleistocene, suggesting the potential for strong baseflow in an area that today experiences only ephemeral river flow (Guerreiro et al., 2018). Thus, new data from LN hold the potential for helping to clarify environmental conditions in the wetlands during the late glacial and deglacial period. In general, our data suggest that fluvial dynamics are important controls on floodplain depositional environments and local vegetation patterns (Fig. 7). Precipitation in the catchment is the primary regulator of river flooding, which responds to the intensity, duration, and recurrence time of the South America summer monsoon (Stevaux and Latrubesse, 2017). Because floodplain lakes share hydrological and morphological connections to rivers that vary, the 

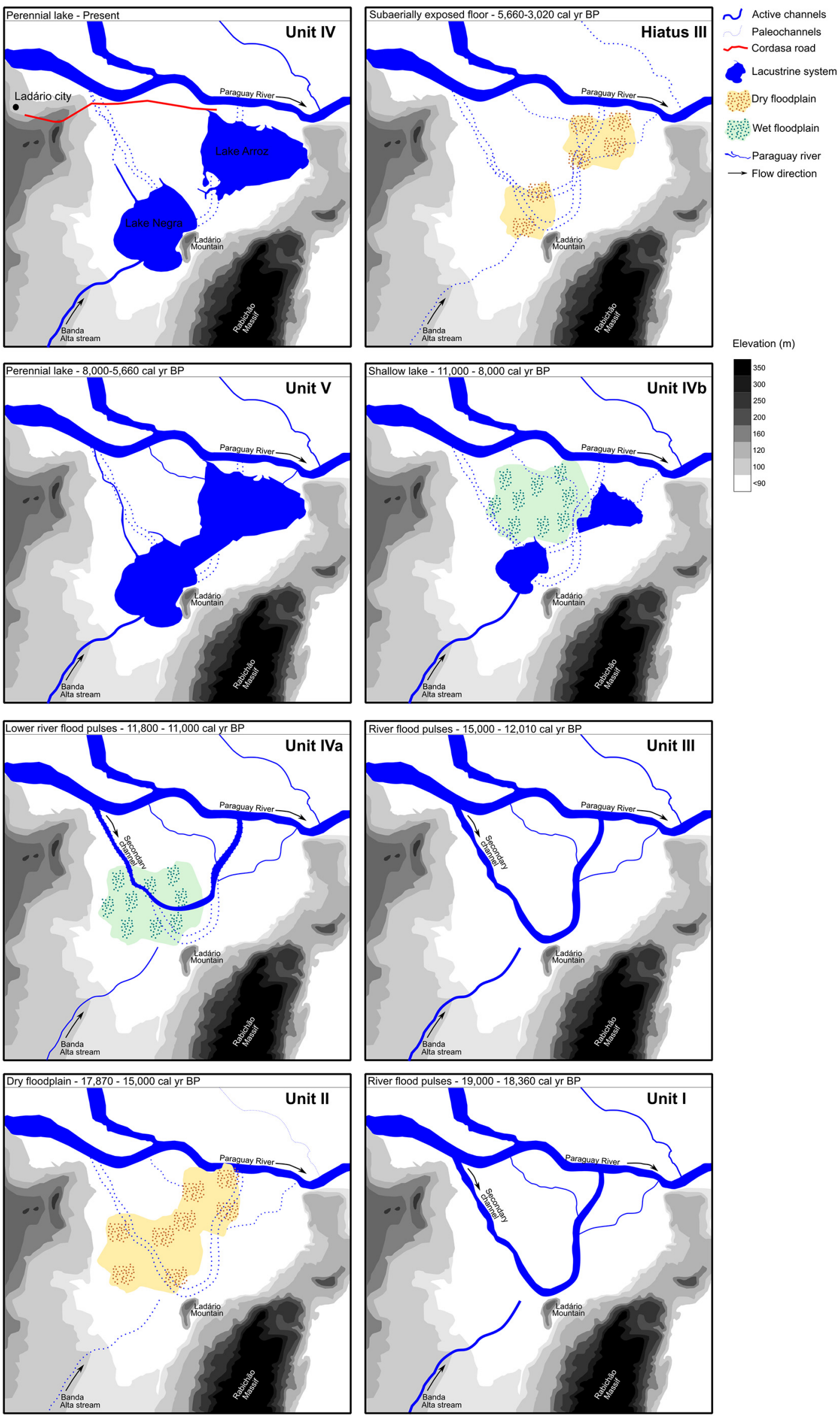


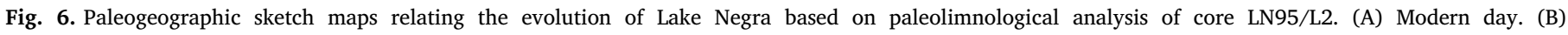

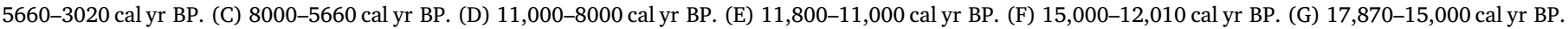
(H) $19,000-18,360$ cal yr BP.

sedimentary records of these basins must be interpreted through the filter of fluvial history.

Our study used new geochronology, core sedimentology, phytoliths and sponge spicules in order to improve paleoenvironmental interpretations for LN over the last 19,000 yr (Fig. 7). In Brazil, studies that use phytoliths as indicators of paleoenvironments have been restricted to coastal environments, peatlands, or soils from only a few states, including Rio de Janeiro (Coe et al., 2013; Coe et al., 2014), Espírito Santo (Lorente et al., 2015), São Paulo (Calegari et al., 2015), Paraná (Rasbold et al., 2016; Parolin et al., 2017; Monteiro et al., 2015), and Minas Gerais (Augustin et al., 2014; Coe et al., 2015; Barros et al., 2016). Thus, our study is the first to apply phytolith analysis to fluvial lacustrine sediments from the Pantanal. Additional geochronological information revealed the presence of three hiatuses in the LN sedimentary sequence. Late Pleistocene hiatuses are interpreted to be the result of erosion from fluvial scour that removed section; these are consistent with wet climatic conditions and riverine processes affecting the core site inferred by Bezerra and Mozeto (2008). The late Holocene hiatus was non-depositional and most likely driven by subaerial exposure of LN during a prolonged interval of drought, which has been observed in other paleoenvironmental archives from central Pantanal (McGlue et al., 2012).

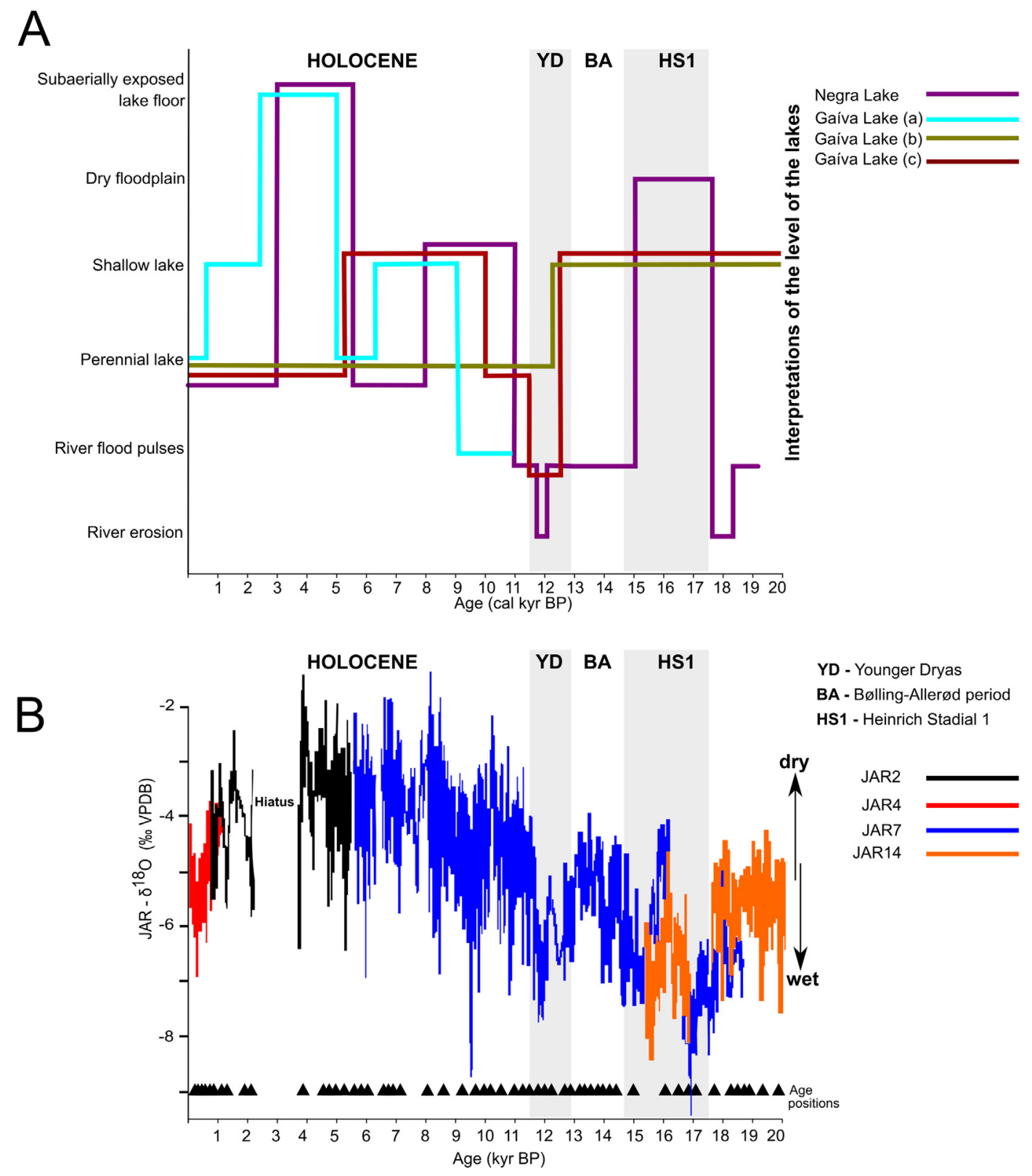

Fig. 7. Regional comparison of our data with paleo-records from elsewhere in the Pantanal wetlands of Brazil. (A) Data from floodplain lakes in central Pantanal (Lakes Negra and Gaíva; Whitney et al., 2011; McGlue et al., 2012; Metcalfe et al., 2014) plotted against (B) $\delta^{18}$ O records from caves (Novello et al., 2017; Novello, 2016). 


\subsection{Pleistocene late glacial and deglacial}

The presence of massive sand and an absence of siliceous microfossils reveal that, unlike the modern LN condition, the environment was strongly influenced by fluvial channel sedimentary processes during two intervals of the late Pleistocene: $\sim 19,000-18,360$ and $\sim 15,000-12,010$ cal yr BP (e.g., Units I and III). The geochemical data presented in Bezerra and Mozeto (2008) for LN suggest that prior to $\sim 11,000$ cal yr BP, there were two peaks of deposition under the strong influence of the Paraguay River, separated by an intervening phase with only minor fluvial influence when fine grained, organic rich sediments were deposited. These interpretations are supported by our microfossil data and age model refinements for Units I, II and III. We interpret that wet climatic conditions during Units I and III allowed riverine flooding and potentially avulsions to influence the LN floodplain. Some of the best late Pleistocene paleo-precipitation data available for the Pantanal comes from Jaraguá cave speleothem $\delta^{18} \mathrm{O}$, which provide a proxy for monsoon strength (Novello, 2016; Novello et al., 2017). These datasets confirm that the monsoon was strong during the last glacial period ( 27.9-17.8 kyr BP), Heinrich Stadial 1 ( $\sim 17.7-14.8 \mathrm{kyr} \mathrm{BP})$, and the Younger Dryas (12.9-11.6 kyr BP). By contrast, the cave carbonate records indicate a relatively dry Bølling-Allerød period ( 14.7-12.9 kyr BP). Deposition of river-derived sand at the LN coring site began during wet phases in the Pantanal, when the SASM was strong. We interpret that floods from the Paraguay River trunk channel itself, or from an associated secondary channel, helped to deliver sand to the core site on the LN floodplain.

Anabranching channels are common for the Paraguay River in the Pantanal basin. Secondary channels that bifurcate from and rejoin the Paraguay River vary in morphology, size, permanence, and many of them are active only during floods. LN is located in the ParaguayCorumbá geomorphic compartment of the Pantanal, which is a $\sim 27 \mathrm{~km}$ wide heterogenous floodplain with both active and ancient channels (Assine et al., 2015b). We interpret that a secondary channel connected to the Paraguay River that formed in the late Pleistocene was responsible for depositing Unit I and III sands. Anastomosing river channels are often narrow and complex, bifurcating numerous times around relatively stable vegetated islands. Makaske (2001) noted that avulsions are key for anastomosing rivers to evolve, and avulsion frequency can be driven by depositional rates and channel discharge, or changes in base level and regional gradient. High depositional rates and the formation of alluvial ridges and levees can spur avulsions, which allows for the development of multiple active channel belts. Secondary channel development and the deposition of muddy sands are consistent with the period of intense monsoon rainfall in the late deglacial recorded at Jaraguá cave (Novello et al., 2017). The Pantanal basin's geomorphology is amenable to the development of anastomosing river channels due to low gradient valleys and flood-prone discharge, as well as cohesive bank sediments and abundant organic debris in certain locales.

Separating the two fluvio-lacustrine phases there was a shallow wetland phase from $\sim 17,880$ to $15,000 \mathrm{cal}$ yr BP, which we interpret to have resulted from drier conditions and evaporation of ponded water on the floodplain. The presence of carbonate at the core site, as well as bulliform-type phytoliths and fragmented sponge megascleres, are consistent with a seasonally dry climate and a floodplain lake that experienced evaporative conditions and a fluctuating shallow water column. The nearly exclusive deposition of fragmented megascleres indicates an unstable aquatic environment, with possible reworking by occasional floods (Kuerten et al., 2013). A perennial lake is much less likely than an ephemeral lake from $\sim 17,800$ to 15,000 cal yr BP, because perennial lakes in the Pantanal typically contain sponge fossils with preserved gemmuloscleres and microscleres that are highly dissimilar to the fossil record of Unit II. Yet this time interval overlaps with Heinrich Stadial 1 (HS1), when the Pantanal was hydroclimatically complex. According to Novello et al. (2017), HS1 was marked by a wet early phase $(\sim 17.7-16.8 \mathrm{kyr} \mathrm{BP})$, a relatively dry intermediate phase ( $\sim 16.5-16.0 \mathrm{kyr}$ BP), and a wet conclusion ( $\sim 16.0-14.8 \mathrm{kyr}$ BP). Unit II deposits suggest that the LN site responded to the dry middle phase of HS1, and that depositional patterns were influenced by a decline in precipitation. Bezerra and Mozeto (2008) suggested that late Pleistocene intervals characterized by lacustrine sedimentation may have occurred during relatively dry intervals, when baseflow within the adjacent rivers was low. This interpretation is consistent with evidence from our record, though we suggest that residence time was too short for a true lacustrine environment to develop. Mottled muds in Unit II are more consistent with a fluctuating floodplain wetland that received rare floods from the adjacent river system, which was mostly confined to its channel.

\subsection{Early Holocene}

Several lines of evidence suggest that the transition into the early Holocene was marked by a change in environmental conditions at LN. Beginning with Unit IVb, the abundance and diversity of sponge microfossils increase markedly, and phytoliths morphotypes from $\mathrm{C}_{3}$ and $\mathrm{C}_{4}$ grasses as well as globular morphologies increase. Furthermore, the organic carbon content of core sediments increases in Unit IVb and reaches a maximum in Unit $\mathrm{V}$ (Fig. 4). We interpret that by $\sim 8000$ cal yr BP, a perennial lake had formed at the LN core site (Fig. 6). Our data suggest that very limited riverine flooding occurred during the deposition of Units IVb and V. Oxygen isotope data from Jaraguá cave show that the last $\sim 11,000$ yrs were drier compared to the LGM and deglacial, with very short intervals of high rainfall occurring occasionally (Novello et al., 2017). Although precipitation overall was lower in the Holocene relative to the Pleistocene, seasonal rainfall was apparently sufficient to maintain a perennial lake system while keeping the Paraguay River mostly confined within its channel, as evidence for flooding is minimal.

Sponges respond to local environmental conditions, and they are particularly sensitive to changes associated with flowing versus stagnant waters and transport distance. For example, sponge assemblages marked by robust structures (e.g., megascleres) and a high degree of fragmentation are most consistent with long distance fluvial transport, whereas a biodiverse assemblage of delicate spicules suggests a local lacustrine population under stable conditions (Wilding and Drees, 1968; Sifeddine et al., 2001; Santos et al., 2016). The development of a spongiofacies in Unit $\mathrm{V}$ indicates that the environmental conditions at LN were a shallow lake with abundant macrophytes on its margins. Excellent preservation of $C$. heterosclera and $H$. barlettai spicules between $\sim 8000$ and $5700 \mathrm{cal} \mathrm{yr} \mathrm{BP}$ is a lodestar of this stable lacustrine environment. Microcleres and gemmuloscleres are the smallest siliceous structures of the freshwater sponge skeleton. The elongate and spined microscleres in Unit $\mathrm{V}$ do not exceed $\sim 100 \mu \mathrm{m}$ long, and their unique and pristine preservation state suggests that remobilization was uncommon (Fig. 5). Besides the taphonomic condition of the spicules, the ecological characteristics of the species are valuable for characterizing the paleoenvironment. $H$. barlettai are characteristic of lentic environments, and they are frequently found attached to roots of aquatic plants (Pinheiro et al., 2015). C. heterosclera prefers to settle on floating macrophyte roots in highly vegetated ponds (Ezcurra de Drago, 1974). The spicules of $C$. heterosclera in the sediments of the LN were well preserved, in evidence from the positive identification of three types of microscleres that are characteristic of this species: (i) Pseudobirotule microsclere with pseudobirotules of long hooks, (ii) Pseudobirotule microsclere with pseudobirotules of short hooks, and iii) Acanthoxea microscleres (Fig. 7). Although C. heterosclera and $H$. barlettai are dominant in Unit V, the presence of T. paulula, T. variabilis, R. amazonensis are further evidence of a lentic ecosystem, as these species are known from modern environments to prefer lakes with abundant submerged vegetation (Volkmer-Ribeiro et al., 1975; Volkmer-Ribeiro and De Rosa-Barbosa, 1985; Tavares et al., 2003). The less common spicules 
like D. pydanieli and C. seckti are known to attach submerged roots, stems of aquatic plants or on rocky substrates that experience period inflows (Volkmer-Ribeiro and Parolin, 2010).

Bezerra and Mozeto (2008) indicate that around 11,000 yr BP, a set of levees may have developed that isolated LN from the Paraguay River; they pointed towards elevated organic carbon in the early Holocene as key evidence for this geomorphological change. Those authors argued that regional evidence for fluvial transport of bedload sediment in the late Pleistocene under conditions of high rainfall may have built floodplain landforms that allowed lake development to occur in isolation from large rivers. If accurate, the development of positive relief constructional landforms in the area of LN may have helped the lake expand during a time of relatively low precipitation. Cohen et al. (2015) note that in the foreland settings, the development of topographic closure and lakes occurs under conditions where sediment infill from large rivers is modulated, by a dry climate or geomorphic processes that isolate the available accommodation for water and sediment.

The transition between units V and VI is unconformable, and we interpret that regional drought was responsible for setting in motion processes that removed section at the mid-to-late Holocene transition. The stratal contact in LN95/2 is marked by a sharp boundary with strong evidence for oxidation of a formerly subaqueous depositional environment, including sand and gravel-sized iron oxide grains overlying dark muds. Our BACON age model suggests that this event took place at the transition to the late Holocene. The existence of severe midHolocene drought in the Pantanal has been debated. McGlue et al. (2012) reported the existence of a hiatus that removed section from 5300 to 2600 cal yr BP in lakes Gaíva and Mandiore, which were attributed to the exposure of the lake's floor due to a drought-induced regression accompanying a low, channel confined Paraguay River. However, Metcalfe et al. (2014), also studying Lake Gaiva, found no evidence for a prolonged drought. Rather, those authors suggested a deep and stable lake based on diatom assemblages from 5000 to 2100 cal yr BP. Similarly, a Pediastrum (green siliceous algae) paleoecological record described in Whitney and Mayle (2012) from Lake Gaiva indicates relatively low water levels in the early Holocene, followed by progressively wetter conditions after $\sim 4400$ cal yr BP. Yet a paucity of growth bands in stalagmites from Mato Grosso do Sul suggested limited water availability between 3800 and 2500 yr BP (Bertaux et al., 2002). Most recently, stalagmites from Jaraguá cave provides compelling evidence for dry conditions $\sim 3670-2170$ yr BP, when stalagmite growth halted entirely (Novello, 2016). Given the robust dating associated with the Jaragua cave record, we suggest that a prolonged drought at the transition to the late Holocene was most likely, and that this event desiccated LN.

\subsection{Late Holocene}

The quantity of biological indicators abruptly decreases at the transition into Unit VI $(<100$ phytoliths, $<200$ megascleres, $<4$ gemmuloscleres, and 1 microsclere) and remains low throughout the unit. $R$. amazonensis sponge spicules were found in the top of the unit (Fig. 4). This is a lentic sponge that tends to occupy shallow lakes with abundant vegetation (Volkmer-Ribeiro and Parolin, 2010). The predominant phytoliths in Unit VI are the robust cuneiform, parallepipedal, and elongate psilate morphologies. After $\sim 1000 \mathrm{yr}$ BP, globular echinate phytoliths are present, (Bromeliaceae - Piperno, 1985, 2006; Bremond et al., 2005 and Arecaceae - Piperno, 2006; Runge, 1999; Mercader et al., 2009) and this type corresponds to vegetation surrounding the lake today, such as bromeliads are dominant in the Ladário Mountain and specimens of C. alba (Carandá-Arecaceae) dominate the landscape along the northwest and southwestern shores of LN. Together, the biological indicators and sedimentology of Unit VI suggest a reorganization of the depositional environment following late Holocene drought that produced a shallow, fluctuating floodplain lake that accumulates little organic carbon, most likely due to conditions that do not favor preservation. We interpreted that $\mathrm{LN}$ achieved a nearmodern morphology and bathymetry $\sim 1000 \mathrm{cal} \mathrm{yr} \mathrm{BP}$, as the sponge fauna and vegetation assemblies become similar to the present at that time. This interpretation is consistent with regional paleoclimate archives that suggest wetter conditions in the latest Holocene, including a stalagmite from João Arruda cave (Bonito, MS), which showed approximately constant growth since $\sim 2500$ yr BP (Bertaux et al., 2002). Oxygen isotopes from the Pau d'Alho cave (northern border of Pantanal) indicate that the Little Ice Age was wet, and that a persistent rainfall cycle has occurred over the past $\sim 1500 \mathrm{yr} B P$ in the area (Novello et al., 2016). Lakes from elsewhere in the Pantanal, including the Nhecolândia region, recorded shifting depositional conditions after $\sim 3200$ cal yr BP, with marked change in salinity and alkalinity in the last millennium (Guerreiro et al., 2018; McGlue et al., 2017).

\section{Conclusions}

1. A sediment core from Lake Negra, a shallow floodplain lake in central Pantanal, tropical western Brazil, provides new paleoenvironmental information for a region that remains difficult to access. Late Quaternary responses of tropical wetlands to climate are important for understanding the sensitivity of these aquatic ecosystems to alterations in the water cycle. The chronology of the core was established using ${ }^{14} \mathrm{C}$ dating and OSL. The sedimentary record extends to $\sim 19,000$ cal yr BP and it is punctuated by three short hiatuses. The study is the first of its kind to integrate core sedimentology with phytolith and sponge spicule analysis for the purpose of reconstructing environmental history in the Pantanal. Proportional changes in the abundance of sponges and phytoliths show considerable sensitivity to hydroclimatic and changes in depositional environment.

2. The accumulation of muddy sands in the late Pleistocene is consistent with deposition influenced by fluvial processes under a strong monsoon. A secondary anabranching channel associated with the Paraguay River system may have occupied the area of the present-day LN during the deglacial when the climate was wet. A brief dry episode during the complex Heinrich Stadial 1 appears to have resulted in an ephemeral wetland at the LN site.

3. In spite of a decline in monsoon rainfall in the early-middle Holocene in Pantanal, a stable lacustrine environment expanded at Lake Negra beginning $\sim 11,000 \mathrm{yr}$ BP, which may be explained by isolation of the floodplain from the Paraguay River system, either from channel confinement (low baseflow) or from the construction of levees. The immaculate preservation of phytoliths and delicate sponge spicules (microscleres) indicate that this lacustrine environment, though shallow, was stable between $\sim 8000$ and $\sim 5660$ cal yr BP.

4. Missing section from $\sim 5660$ to 3020 cal yr BP suggests that a late Holocene drought dessicated $\mathrm{LN}$ at the transition into the late Holocene; this evidence is consistent with oxygen isotopes and growth rings in speleothems from elsewhere in the Pantanal. LN appears to have established near-modern characteristics around 1000 cal yr BP.

5. Data from LN suggest that floodplain lakes in the Pantanal respond in a complex and at times indirect manner to climate change, and the dynamics of the adjacent fluvial system must be accounted for when interpreting paleohydrology and vegetation patterns.

\section{Acknowledgments}

The first author thanks the Coordination for the Improvement of High Education Personal (CAPES) for a scholarship and PROEX/CAPES. AS acknowledges grant support from CNPq (431253/2018-8). We appreciate the support of the Paleo-environmental studies Laboratory of Fecilcam, Lepafe at the State University of Paraná, the Research Group 
in Limnology, Ichthyology and Aquaculture, Nupélia, at the State University of Maringá. Thanks to Prof. Dr. William Marcos da Silva, coordinator of the Laboratory of Ecology at UFMS - Pantanal Campus. SISBIO provided authorization for scientific research activities associated with this project (60099). We thank our reviewers and editors for their generous and helpful comments.

\section{Appendix A. Supplementary data}

Supplementary data to this article can be found online at https:// doi.org/10.1016/j.palaeo.2019.01.015.

\section{References}

Ab'Saber, A.N., 1988. O Pantanal Mato-Grossense e a teoria dos refúgios. Rev. Bras. Geogr. 50 (2), 9-57.

Assine, M.L., Soares, P.C., 2004. Quaternary of the Pantanal, west-central Brazil. Quat. Int. 114, 23-34. https://doi.org/10.1016/S1040-6182(03)00039-9.

Assine, M.L., Merino, E.R., Pupim, F.N., Macedo, H.A., Santos, M.G.M., 2015a. The Quaternary alluvial systems tract of the Pantanal Basin, Brazil. Brazilian Journal of Geology 45 (3), 475-489. https://doi.org/10.1590/2317-4889201520150014.

Assine, M.L., Merino, E.R., Pupim, F.N., Warren, L.V., Guerreiro, R.L., McGlue, M.M., 2015b. Geology and geomorphology of the Pantanal Basin. In: Bergier, I., Assine, M.L. (Eds.), Dynamics of the Pantanal Wetland in South America. The Handbook of Environmental Chemistry 37. Springer, Cham, pp. 23-50. https://doi.org/10.1007/ 698_2015_349.

Assumpção, M., Dias, F.L., Zevallos, I., Naliboff, J.B., 2016. Intraplate stress field in South America from earthquake focal mechanisms. J. S. Am. Earth Sci. 71, 278-295. https://doi.org/10.1016/j.jsames.2016.07.005.

Augustin, C.H.R.R., Coe, H.H.G., Chueng, K.F., 2014. Analysis of geomorphic dynamics in ancient quartzite landscape using phytolith and carbon isotopes, Espinhaço Mountain Range, Minas Gerais, Brazil. Geomorphologie 4, 355-376.

Barros, L.F.P., Coe, H.H.G., Seixas, A.P., Magalhães, A.P., Macario, K.C.D., 2016 Paleobiogeoclimatic scenarios of the Late Quaternary inferred from fluvial deposits of the Quadrilátero Ferrífero (Southeastern Brazil). J. S. Am. Earth Sci. 67, 71-88. https://doi.org/10.1016/j.jsames.2016.02.004.

Bergier, I., Assine, M.L., McGlue, M.M., Alho, C.J.R., Silva, A., Guerreiro, R.L., Carvalho, J.C., 2018. Amazon rainforest modulation of water security in the Pantanal wetland. Sci. Total Environ. 619-620, 1116-1125. https://doi.org/10.1016/j.scitotenv.2017. 11.163.

Bertaux, J., Sondag, F., Santos, R., Soubies, F., Casse, C., Plagnes, V., Le Cornec, F., Seidel, F., 2002. Palaeoclimatic record of speleothems in a tropical region: study of laminated sequences from a Holocene stalagmite in central-west Brazil. Quat. Int. 89, 3-16. https://doi.org/10.1016/S1040-6182(01)00077-5.

Bezerra, M.A.O., 1998. Uso de multi-traçadores na reconstrução de Holoceno no Pantanal Mato-grossense, Corumbá, MS. Ph.D. Thesis In: Ecologia e Recursos Naturais. Universidade de São Carlos, São Carlos, SP 254 p.

Bezerra, M.A.O., Mozeto, A.A., 2008. Deposição de carbono orgânico na planície de inundação do Rio Paraguai durante o Holoceno médio. Oecologia Brasiliensis 12 (1), 155-171.

Blaauw, M., Christen, J.A., 2011. Flexible paleoclimate age-depth models using an autoregressive gamma process. Bayesian Anal. 6 (3), 457-474.

Brasil Ministério de Minas e Energia. Secretaria-Geral. Projeto RADAMBRASIL. Folha SE. 21 Corumbá e parte da Folha SE.20; geologia, geomorfologia, pedologia, vegetação e uso potencial da terra. Rio de Janeiro, 1982. $452 \mathrm{p}$.

Bremond, L., Alexandre, A., Peyron, O., Guiot, J., 2005. Grass water stress estimated from phytoliths in West Africa. J. Biogeogr. 32, 311-327. https://doi.org/10.1111/j.13652699.2004.01162.x.

Bridgham, S.D., Cadillo-Quiroz, H., Keller, J.K., Zhuang, Q., 2013. Methane emissions from wetlands: biogeochemical, microbial, and modeling perspectives from local to global scales. Glob. Chang. Biol. 19 (5), 1325-1346. https://doi.org/10.1111/gcb. 12131.

Calegari, M.R., Madella, M., Buso Jr., A.A., Osterrieth, M., Lorente, F.L., Pessenda, L.C.R., 2015. Holocene vegetation and climate inferences from phytoliths and pollen from Lagoa do Macuco, North Coast of Espírito Santo State (Brazil). Quaternary and Environmental Geosciences 6, 41-50. https://doi.org/10.5380/abequa.v6i1.36426.

Calheira, L., Pinheiro, U., 2016. Corvoheteromeyenia Ezcurra de Drago, 1979 (Spongillidae, Porifera): genus review with proposal of neotype of Corvoheteromeyenia heterosclera (Ezcurra de Drago, 1974). Zootaxa 4126 (3), 351-374. https://doi.org/10.11646/zootaxa.4126.3.3.

Coe, H.H.G., Alexandre, A., Carvalho, C.N., Santos, G.M., Da Silva, A.S., Sousa, L.O.F., Lepsch, I.F., 2013. Changes in Holocene tree cover density in Cabo Frio (Rio de Janeiro, Brazil): evidence from soil phytolith assemblages. Quat. Int. 287, 63-72. https://doi.org/10.1016/j.quaint.2012.02.044.

Coe, H.H.G., Kita, M., Gomes, J.G., Chueng, K.F., Oliveira, F., Gomes, P.R.S., Carvalho, C., Linares, R., Alves, E., Santos, G.M., 2014. Understanding Holocene variations in the vegetation of Sao Joao River basin, southeastern coast of Brazil, using phytolith and carbon isotopic analyses. Palaeogeogr. Palaeoclimatol. Palaeoecol. 415, 59-68. https://doi.org/10.1016/j.palaeo.2014.01.009.

Coe, H.H.G., Seixas, A.P., Gomes, J.G., Barros, L.F.P., 2015. Reconstituição Paleobiogeoclimática através de Fitólitos e Isótopos de Carbono no Quadrilátero
Ferrífero, MG. Revista Equador 4, 1439-1447.

Cohen, A.S., 2003. Paleolimnology: The History and Evolution of Lake Systems. Oxford University Press, Oxford 528p.

Cohen, A.S., McGlue, M.M., Ellis, G.S., Zani, H., Swarzenski, P.W., Assine, M.L., Silva, A., 2015. Lake formation, characteristics, and evolution in retroarc deposystems: a synthesis of the modern Andean orogen and its associated basins. In: DeCelles, P.G., Ducea, M.N., Carrapa, B., Kapp, P.A. (Eds.), Geodynamics of a Cordilleran Orogenic System: The Central Andes of Argentina and Northern Chile. Geological Society of America Memoir 212. https://doi.org/10.1130/2015.1212(16).

Dias, F.L., Assumpcão, M., Facincani, E.M., Franca, G.S., Assine, M.L., Paranhos Filho, A.C., Gamarra, R.M., 2016. The 2009 earthquake, magnitude mb 4.8, in the Pantanal Wetlands, west-central Brazil. An. Acad. Bras. Cienc. 88 (3), 1253-1264.

Ezcurra de Drago, I., 1974. Las especies sudamericanas de Corvomeyenia Weltner (Porifera, Spongillidae). Physis 33 (87), 233-240.

Fornace, K.L., Whitney, B.S., Galy, V., Hughen, K.A., Mayle, F.E., 2016. Late Quaternary environmental change in the interior South American tropics: new insight from leaf wax stable isotopes. Earth Planet. Sci. Lett. 438, 75-85. https://doi.org/10.1016/j. epsl.2016.01.007.

Foti, R., del Jesus, M., Rinaldo, A., Rodriguez-Iturbe, I., 2013. Signs of critical transition in the Everglades wetlands in response to climate and anthropogenic changes. Proc. Natl. Acad. Sci. 110 (16), 6296-6300. https://doi.org/10.1073/pnas.1302558110.

Garreaud, R.D., Vuille, M., Compagnucci, R., Marengo, J., 2009. Present-day South American climate. Palaeogeogr. Palaeoclimatol. Palaeoecol. 281, 180-195. https:// doi.org/10.1016/j.palaeo.2007.10.032.

Gedney, N., Cox, P.M., Huntingford, C., 2004. Climate feedback from methane emissions. Geophysical Research Letters 31, L20503. https://doi.org/10.1029/22004GL020919.

Grimm, E.C., 1987. CONISS: a Fortran 77 program for stratigraphically constrained cluster analysis by the method of incremental sum of squares. Comput. Geosci. 13 (1), 13-35. https://doi.org/10.1016/0098-3004(87)90022-7.

Guerreiro, R.L., McGlue, M.M., Stone, J.R., Bergier, I., Parolin, M., Caminha, S.A.F.S., Warren, L., Assine, M., 2018. Paleoecology explains Holocene chemical changes in lakes of the Nhecolândia (Pantanal-Brazil). Hydrobiologia 815 (1), 1-19. https://doi. org/10.1007/s10750-017-3429-3.

Hogg, A.G., Hua, Q., Blackwell, P.G., Niu, M., Buck, C.E., Guilderson, T.P., Heaton, T.J., Palmer, J.G., Reimer, P.J., Reimer, R.W., Turney, C.S.M., Zimmerman, S.R.H., 2013 SHCal13 Southern Hemisphere calibration, 0-50,000 years cal BP. Radiocarbon 55 (4), 1889-1903. https://doi.org/10.2458/azu js rc.55.16783.

Hua, Q., Barbetti, M., Rakowski, A.Z., 2013. Atmospheric radiocarbon for the period 1950-2010. Radiocarbon 55 (4), 2059-2072. https://doi.org/10.2458/azu_js_rc v55i2.16177.

Hutchinson, G.E., 1957. A Treatise on Limnology, v. 1. Geography, Physics and Chemistry J. Wiley and Sons, New York 1015 p.

Junk, W.J., 2002. Long-term environmental trends and the future of tropical wetlands. Environ. Conserv. 29 (4), 414-435. https://doi.org/10.1017/S0376892902000310.

Junk, W.J., An, S., Finlayson, C.M., Gopal, B., Kvě, M., Stephen, A., Mitsch, W.J., Robarts, R.D., 2013. Current state of knowledge regarding the world-s wetlands and their future under global climate change: a synthesis. Aquat. Sci. 75, 151-167. https://doi. org/10.1007/s00027-012-0278-z.

Kuerten, S., Parolin, M., Assine, M., McGlue, M.M., 2013. Sponge spicules indicate Holocene environmental changes on the Nabileque River floodplain, southern Pantanal, Brazil. J. Paleolimnol. 49 (2), 171-183. https://doi.org/10.1007/s10933012-9652-z.

Lacerda Filho, J.V., Silva, M.G., Hardy, J., 2006. Geologia e recursos minerais do Estado de Mato Grosso do Sul: texto explicativo dos mapas geológico e de recursos minerais do Estado de Mato Grosso do Sul: escala 1:1.000.000. CPRM-Serviço Geológico do Brasil, Campo Grande 121 p.

Lorente, F.L., Pessenda, L.C.R., Calegari, M.R., Cohen, M.C.L., Rossetti, D.F., Giannini, P.C.F., Buso Junior, A.A., Castro, D.F., Franca, M.C., Bendassolli, J.A., Macario, K., 2015. Fitólitos como indicadores de mudanças ambientais durante o Holoceno na costa norte do estado do Espírito Santo (Brasil). Quaternary and Environmental Geosciences 6, 26-40. https://doi.org/10.5380/abequa.v6i1.36239.

Madella, M., Alexandre, A., Ball, T., 2005. International code for phytolith nomenclature 1.0. Ann. Bot. 96 (2), 253-260. https://doi.org/10.1093/aob/mci172.

Makaske, B., 2001. Anastomosing rivers: a review of their classification, origin and sedimentary products. Earth-Sci. Rev. 53, 149-196. https://doi.org/10.1016/S0012 8252(00)00038-6.

Manconi, R., Pronzato, R., 2002. Sub-order Spongillina subord. nov.: freshwater sponges. In: Hooper, J.N.A., Van Soestr, W.M. (Eds.), Systema Porifera: A Guide to the Classification of Sponges. Kluwer Academic/Plenum Publ, New York, pp. 921-1019. https://doi.org/10.1007/978-1-4615-0747-5_97.

McGlue, M.M., Silva, A., Corradini, F.A., Zani, H., Trees, M.A., Ellis, G.E., Parolin, M., Swarzenski, P.W., Cohen, A.S., Assine, M.L., 2011. Limnogeology in Brazil's "forgotten wilderness": a synthesis from the large floodplain lakes of the Pantanal. J. Paleolimnol. 46, 273-289. https://doi.org/10.1007/s10933-011-9538-5.

McGlue, M.M., Silva, A., Zani, H., Corradini, F.A., Parolin, M., Abel, E.J., Cohen, A.S., Assine, M.L., Ellis, G.S., Trees, M.A., Kuerten, S., Gradella, F.S., Rasbold, G.G., 2012 Lacustrine records of Holocene flood pulse dynamics in the Upper Paraguay River watershed (Pantanal wetlands, Brazil). Quat. Res. 78, 285-294. https://doi.org/10. 1016/j.yqres.2012.05.015.

McGlue, M.M., Silva, A., Assine, M.L., Stevaux, J.C., Pupim, F.N., 2015. Paleolimnology in the Pantanal: using lake sediments to track quaternary environmental change in the world's largest tropical wetland. In: Bergier, I., Assine, M.L. (Eds.), Dynamics of the Pantanal Wetland in South America. The Handbook of Environmental Chemistry 37. Springer, Cham, pp. 51-81. https://doi.org/10.1007/698_2015_350.

McGlue, M.M., Guerreiro, R.L., Bergier, I., Silva, A., Pupim, F., Oberc, V., Assine, M., 2017. Holocene stratigraphic evolution of saline lakes in Nhecolândia, southern 
Pantanal wetlands (Brazil). Quat. Res. 88 (3), 472-490. https://doi.org/10.1017/ qua.2017.57.

Melton, J.R., Wania, R., Hodson, E.L., Poulter, B., Ringeval, B., Spahni, R., Bohn, T., Avis, C.A., Beerling, D.J., Chen, G., Eliseev, A.V., Denisov, S.N., Hopcroft, P.O., Lettenmaier, D.P., Riley, W.J., Singarayer, J.S., Subin, Z.M., Tian, H., Zürcher, S., Brovkin, V., Bodegom, Van, Kleinen, T., Yu, Z.C., Kaplan, J.O., 2013. Present state of global wetland extent and wetland methane modelling: conclusions from a model intercomparison project (WETCHIMP). Biogeosciences 10, 753-788. https://doi.org/ 10.5194/bg-10-753-2013.

Mercader, J., Bennett, T., Esselmont, C., Simpson, S., Walde, D., 2009. Phytoliths in woody plants from the Miombo woodlands of Mozambique. Ann. Bot. 104, 91-113. https://doi.org/10.1093/aob/mcp097.

Metcalfe, S.E., Whitney, B.S., Fitzpatrick, K.A., Mayle, F.E., Loader, N.J., Street-Perrott, F.A., Mann, D.G., 2014. Hydrology and climatology at Laguna La Gaiba, lowland Bolivia: complex responses to climatic forcings over the last 25000 years. J. Quat. Sci. 29 (3), 289-300. https://doi.org/10.1002/jqs.2702.

Mitsch, W.J., Nahlik, A., Wolski, P., Bernal, B., Zhang, L., Ramberg, L., 2010. Tropical wetlands: seasonal hydrologic pulsing, carbon sequestration, and methane emissions. Wetl. Ecol. Manag. 18 (5), 573-586. https://doi.org/10.1007/s11273-009-9164-4.

Mitsch, W.J., Bernal, B., Nahlik, A.M., Mander, Ü., Zhang, L., Anderson, C.J., Jørgensen, S.E., Brix, H., 2013. Wetlands, carbon, and climate change. Landsc. Ecol. 28 (4), 583-597. https://doi.org/10.1007/s10980-012-9758-8.

Monteiro, M.R., Parolin, M., Caxambu, M.G., 2015. Análise da assembléia fitolítica em solo superficial e serrapilheira em dois fragmentos de cerrado em área urbana de Campo Mourão-Paraná. Revista Brasileira de Geografia Física 8 (4), 1256-1272.

Morrow, C., Cárdenas, P., 2015. Proposal for a revised classification of the Demospongiae (Porifera). Front. Zool. 12, 7. https://doi.org/10.1186/s12983-015-0099-8.

Nicacio, G., Pinheiro, U., 2015. Biodiversity of freshwater sponges (Porifera: Spongillina) from northeast Brazil: new species and notes on systematics. Zootaxa 3981 (2), 220-240. https://doi.org/10.11646/zootaxa.3981.2.4.

Novello, V.F., 2016. Paleoclima do Centro-Oeste do Brasil desde o último período glacial com base em registros isotópicos de espeleotemas. Ph.D. Thesis In: Geoquímica e Geotectônica. Universidade de São Paulo, São Paulo, SP, Brazil 145 p.

Novello, V.F., Vuille, M., Cruz, F.W., Stríkis, N.M., Paula, M.S., Edwards, R.L., Cheng, H., Karmann, I., Jaqueto, P.F., Trindade, R.I.F., Hartmann, G.A., Moquet, J.S., 2016. Centennial-scale solar forcing of the South American Monsoon System recorded in stalagmites. Sci. Rep. 6, 24762. https://doi.org/10.1038/srep24762.

Novello, V.F., Cruz, F.W., Vuille, M., Stríkis, N.M., Edwards, R.L., Cheng, H., Emerick, S., Saito de Paula, M., Li, X., Barreto, E.S., Karmann, I., Santos, R.V., 2017. A highresolution history of the South American Monsoon from Last Glacial Maximum to the Holocene. Sci. Rep. 7, 44267. https://doi.org/10.1038/srep44267.

Parolin, M., Volkmer-Ribeiro, C., Stevaux, J.C., 2008. Use of Spongofacies as a proxy for river-lake paleohydrology in Quaternary deposits of central-western Brazil. Revista Brasileira de Paleontologia 11 (3), 187-198. https://doi.org/10.4072/rbp.2008.3.05.

Parolin, M., Monteiro, M.R., Coe, H.H.G., Colavite, A.P., 2017. Considerações Paleoambientais do Holoceno Médio por Meio de Fitólitos na Serra do Cadeado, Paraná. Revista do Departamento de Geografia USP 5, 96-103. https://doi.org/10. 11606/rdg.v0ispe.132609.

Parry, W.D., Smithson, F., 1958. Silicification of bulliform cells in grasses. Nature 181, 1549-1550. https://doi.org/10.1038/1811549b0.

Pinheiro, U., Calheira, L., Hajdu, E., 2015. A new species of freshwater sponge, Heteromeyenia barlettai sp. nov. from an aquarium in São Paulo, Brazil (Spongillida: Spongillidae). Zootaxa 4034 (2), 351-363. https://doi.org/10.11646/zootaxa.4034 2.7.

Piperno, P., 1985. Phytolith analysis and tropical paleo-ecology: production and taxonomic signifcance of siliceous forms in new world plant domesticates and wild spe cies. Rev. Palaeobot. Palynol. 45, 185-228. https://doi.org/10.1016/0034-6667(85) 90002-8.

Piperno, D.R., 2006. Phytoliths: A Comprehensive Guide for Archaeologists and Paleoecologists. AltaMira Press, Oxford 238 p.

Por, F.D., 1995. The Pantanal of Mato Grosso (Brazil): World's Largest Wetlands. Kluwer Academic, Dordrecht. https://doi.org/10.1007/978-94-011-0031-1. 125 p.

Pott, A., da Silva, J.S.V., 2015. Terrestrial and aquatic vegetation diversity of the Pantanal Wetland. In: Bergier, I., Assine, M. (Eds.), Dynamics of the Pantanal Wetland in South America. The Handbook of Environmental Chemistry 37. Springer, Cham, pp. 111-131. https://doi.org/10.1007/698 2015 352.

Rasbold, G.G., Parolin, M., Caxambu, M.G., 2016. Reconstrução Paleoambiental de um depósito sedimentary por análises multiproxy, Turvo, estado do Paraná, Brasil. Revista Brasileira de Paleontologia 19 (2), 315-324. https://doi.org/10.4072/rbp. 2016.2.13.

Runge, F., 1999. The opal phytolith inventory of soils in central Africa-quantities, shapes, classifcation, and spectra. Rev. Palaeobot. Palynol. 107, 23-53. https://doi.org/10.
1016/S0034-6667(99)00018-4.

Sangster, G., Parry, W.D., 1969. Some factors in relation to bulliform cell silicifcation in the grass leaf. Ann. Bot. 33, 315-323. https://doi.org/10.1093/oxfordjournals.aob. a084285.

Santos, G.B., Castro, P.T.A., Parolin, M., Doio, L., Costa, D.H., 2016. Análise de espículas de esponjas como indicadores paleoambientais em sedimentos lacustres no oeste da Bahia. Revista Brasileira de Paleontologia 19 (3), 439-448. https://doi.org/10.4072/ rbp.2016.3.09.

Schnurrenberger, D., Russell, J.M., Kelts, K., 2003. Classification of lacustrine sediments based on sedimentary components. J. Paleolimnol. 29 (2), 141-154. https://doi.org/ 10.1023/A:1023270324800.

Shindell, D.T., Chin, M., Dentener, F., Doherty, R.M., Faluvegi, G., Fiore, A.M., Hess, P., Koch, D.M., MacKenzie, I.A., Sanderson, M.G., Schultz, M.G., Schulz, M., Stevenson, D.S., Teich, H., Textor, C., Wild, O., Bergmann, D.J., Bey, I., Bian, H., Cuvelier, C., Duncan, B.N., Folberth, G., Horowitz, L.W., Jonson, J., Kaminski, J.W., Marmer, E., Park, R., Pringle, K.J., Schroeder, S., Szopa, S., Takemura, T., Zeng, G., Keating, T.J., Zuber, A., 2008. A multi-model assessment of pollution transport to the Arctic. Atmos. Chem. Phys. 8, 5353-5372. https://doi.org/10.5194/acp-8-5353-2008.

Sifeddine, A., Martin, L., Turcq, B., Volkmer-Ribeiro, C., Soubiès, F., Cordeiro, R.C., Suguio, K., 2001. Variations of the Amazonian rainforest environment a sedimentological record covering 30,000 years. Palaeogeogr. Palaeoclimatol. Palaeoecol. 168, 221-235. https://doi.org/10.1016/S0031-0182(00)00256-X.

Stevaux, J.C., Latrubesse, E.M., 2017. Geomorfologia Fluvial. Oficina de Textos, São Paulo 336 p.

Tavares, M.C.M., Volkmer-Ribeiro, C., De Rosa-Barbosa, R., 2003. Primeiro registro de Corvoheteromeyenia australis (Bonetto \& Ezcurra de Drago) para o Brasil com chave taxonômica para os poríferos do Parque Estadual Delta do Jacuí, Rio Grande do Sul, Brasil. Revista Brasileira de Zoologia 20 (2), 169-182. https://doi.org/10.1590/ S0101-81752003000200001.

Ussami, N., Shiraiwa, S., Dominguez, J.M.L., 1999. Basement reactivation in a subAndean foreland flexural bulge: the Pantanal wetland, SW Brazil. Tectonics 18 (1), 25-39. https://doi.org/10.1029/1998TC900004.

Volkmer-Ribeiro, C., 1985. Esponjas de Água doce. Manuais Técnicos para a Preparação de Colecões Zoológicas 3, 1-6.

Volkmer-Ribeiro, C., De Rosa-Barbosa, R., 1985. Redescription of the freshwater sponges Trochospongilla repens (Hinde, 1888) and Trochospongilla amazonica (Weltner, 1895) with an account of the South American species of Trochospongilla (Porifera, Spongillidae). Iheringia, Série Zoologia 65, 77-93.

Volkmer-Ribeiro, C., Machado, V.S., 2007. Freshwater sponges (Porifera, Demospongiae) indicators of some coastal habitats in South America: redescriptions and key to identification. Iheringia, Série Zoologia 97 (2), 157-167. https://doi.org/10.1590/ S0073-47212007000200005.

Volkmer-Ribeiro C, Parolin M. 2010. As Esponjas. In: Parolin M, Volkmer-Ribeiro C Leandrini JA (orgs.) Abordagem ambiental interdisciplinar em bacias hidrográficas no Estado do Paraná. Editora da Fecilcam, Campo Mourão, pp 105-130.

Volkmer-Ribeiro, C., Grosser, K.M., De Rosa-Barbosa, R., Pauls, S.M., 1975. Primeiro relato da ocorrência de Espongílideos (Porifera) na Bacia do Guaíba, Estado do Rio Grande do Sul. Theringia, Série Zoologia 46, 33-49.

Vuille, M., Burns, J.S., Taylor, B.L., Cruz, F.W., Bird, B.W., Abbott, M.B., Kanner, L.C., Cheng, H., Novello, V.F., 2012. A review of the South American monsoon history as recorded in stable isotopic proxies over the past two millennia. Clim. Past 8, 1309-1321. https://doi.org/10.5194/cpd-8-637-2012.

Wallinga, J., Murray, A., Wintle, A., 2000. The single-aliquot regenerative-dose (SAR) protocol applied to coarse-grain feldspar. Radiat. Meas. 32 (5-6), 529-533. https:/ doi.org/10.1016/S1350-4487(00)00091-3.

Whitney, B.S., Mayle, F.E., 2012. Pediastrum species as potential indicators of lake-level change in tropical South America. J. Paleolimnol. 47, 601-615. https://doi.org/10. 1007/s10933-012-9583-8.

Whitney, B.S., Mayle, F.E., Punyasena, S.W., Fitzpatrick, K.A., Burn, M.J., Guillen, R., Chavez, E., Mann, D., Pennington, R.T., Metcalfe, S.E., 2011. A 45 kyr palaeoclimate record from the lowland interior of tropical South America. Palaeogeogr. Palaeoclimatol. Palaeoecol. 307 (1-4), 177-192. https://doi.org/10.1016/j.palaeo. 2011.05.012.

Wilding, L.P., Drees, L.R., 1968. Distribution and implications of sponge spicules in surficial deposits in Ohio. The Ohio Journal of Science 68 (2), 92-99.

Zani, H., Assine, M.L., McGlue, M.M., 2012. Remote sensing analysis of depositional landforms in alluvial settings: method development and application to the Taquar megafan, Pantanal (Brazil). Geomorphology 161-162, 82-92. https://doi.org/10. 1016/j.geomorph.2012.04.003.

Zhou, J., Lau, K.M., 1998. Does a monsoon climate exist over South America? J. Clim. 11, 1020-1040. https://doi.org/10.1175/1520-0442(1998)011<1020:DAMCEO > 2.0. $\mathrm{CO} ; 2$ 